\title{
Use of small-scale liquefaction features to assess paleoseismicity: an example from the Saline River fault zone, Southeast Arkansas, USA
}

\author{
Randel T. Cox ${ }^{1}{ }^{*}$, Christopher Lowe ${ }^{1}$, Yanjun Hao ${ }^{2}$ and Shannon A. Mahan ${ }^{3}$ \\ ${ }^{1}$ Department of Earth Sciences, University of Memphis, Memphis, TN, USA \\ ${ }^{2}$ Department of Earth Sciences, Southern Methodist University, Dallas, TX, USA \\ ${ }^{3}$ Luminescence Laboratory, United States Geological Survey, Denver, CO, USA
}

\section{Edited by:}

Alan R. Nelson, United States

Geological Survey, USA

Reviewed by:

R. M. Yuan, China Earthquake Administration, China

Rich D. Koehler, State of Alaska, Division of Geological \& Geophysical Surveys, USA

Alan R. Nelson, United States

Geological Survey, USA

\section{*Correspondence:}

Randel T. Cox, Department of Earth Sciences, University of Memphis,

Johnson Hall, Memphis, TN 38152, USA

e-mail: randycox@memphis.edu
Large-scale liquefaction features (e.g., sand blows, lateral-spread fissure vents) that can be recognized on remote-sensing imagery and photography have been of great utility in developing chronologies of paleo-earthquakes. In areas where large-scale features are obscured on imagery by forest cover and Holocene exposure is lacking, small-scale liquefaction features (e.g., convoluted bedding, clastic intrusions, foundered and suspended blocks, water-escape structures) offer an alternative data source that can be investigated in meter-scale excavations. In order to assess the geographic extent of Holocene sand blow fields in southeast Arkansas that were previously mapped on river terraces and flood plains using aerial photography, we investigated the distribution of small-scale liquefaction features in alluvium along streams within a forested region between the sand blow fields. Our results suggest that the fields are not continuous and do not reflect a single large liquefaction field related to paleo-earthquakes $>M$ 6.5. Features at one of our sites suggests the Desha County sand blow field may be larger than presently mapped, and that the distance from the center of the field to the farthest liquefaction may be $\sim 30 \mathrm{~km}$. The empirical relationship of magnitude and distance to farthest liquefaction suggests a field of this size could have been produced by a M 6.3 earthquake. We also found Holocene liquefaction features that we interpret as resulting from ground shaking near previously documented Pleistocene and Holocene surface ruptures of the Saline River fault zone. Liquefaction during a paleo-earthquake ( M 5.5) may have coincided with movement on that fault zone $\sim A D 1700$.

\section{INTRODUCTION}

The spatial distribution and recurrence intervals of large intraplate earthquakes in eastern North America are poorly understood, and some areas of significant seismic hazard have yet to be adequately characterized. Southeast Arkansas shows evidence of active block tectonics, and regional rivers are aligned with the northwest-southeast structural grain of the deep basement (Figure 1). Geodetic surveys (Meade, 1975; Officer and Drake, 1981; Calais et al., 2006) and geomorphic studies (Schumm et al., 1982; Burnett and Schumm, 1983; Cox, 1994) provide evidence of Quaternary and ongoing uplift and ground tilting in the region. This deformation has been inferred to be related to movements on the Saline River fault zone (Figure 1). Mapping of paleochannels and alluvial terraces associated with the Arkansas, Ouachita, and Saline Rivers indicates late Quaternary westward (up-dip) channel migration across eastward dipping strata of the Mississippi embayment (Schumm et al., 1982; Burnett and Schumm, 1983; Cox, 1994), and Pleistocene and Holocene alluvium is faulted and warped along these river alignments (Cox et al., 2000, 2012).
Although the region is characterized by meager historical seismicity, instrumentally-recorded and/or felt earthquakes ( $<$ M 4.5) in the region are aligned and clustered along southeast flowing rivers, and trenching of sand blows indicates there were larger late Holocene earthquakes in the area (Cox et al., 2000, 2007, 2010, 2012).

Constraints on the timing and location of paleo-earthquakes in the central United States have been greatly aided by the study of liquefaction features (e.g., sand blows and dikes) caused by strong shaking during earthquakes (Munson et al., 1992, 1997; Obermeier et al., 1993; Tuttle and Schweig, 1996; Obermeier, 1998; McNulty and Obermeier, 1999; Tuttle, 2001; Tuttle et al., 2002, 2006). The distance from an epicenter to the farthest liquefaction caused by an earthquake is proportional to the earthquake magnitude and this relationship can be used to estimate the magnitude of paleo-earthquakes (Ambraseys, 1988). There are abundant sand blows and other liquefaction features in southeast Arkansas that are large enough to be readily visible on remote imagery (Cox et al., 2004, 2007, 2010). Several "fields" of largescale liquefaction features (sand blows) are defined primarily 


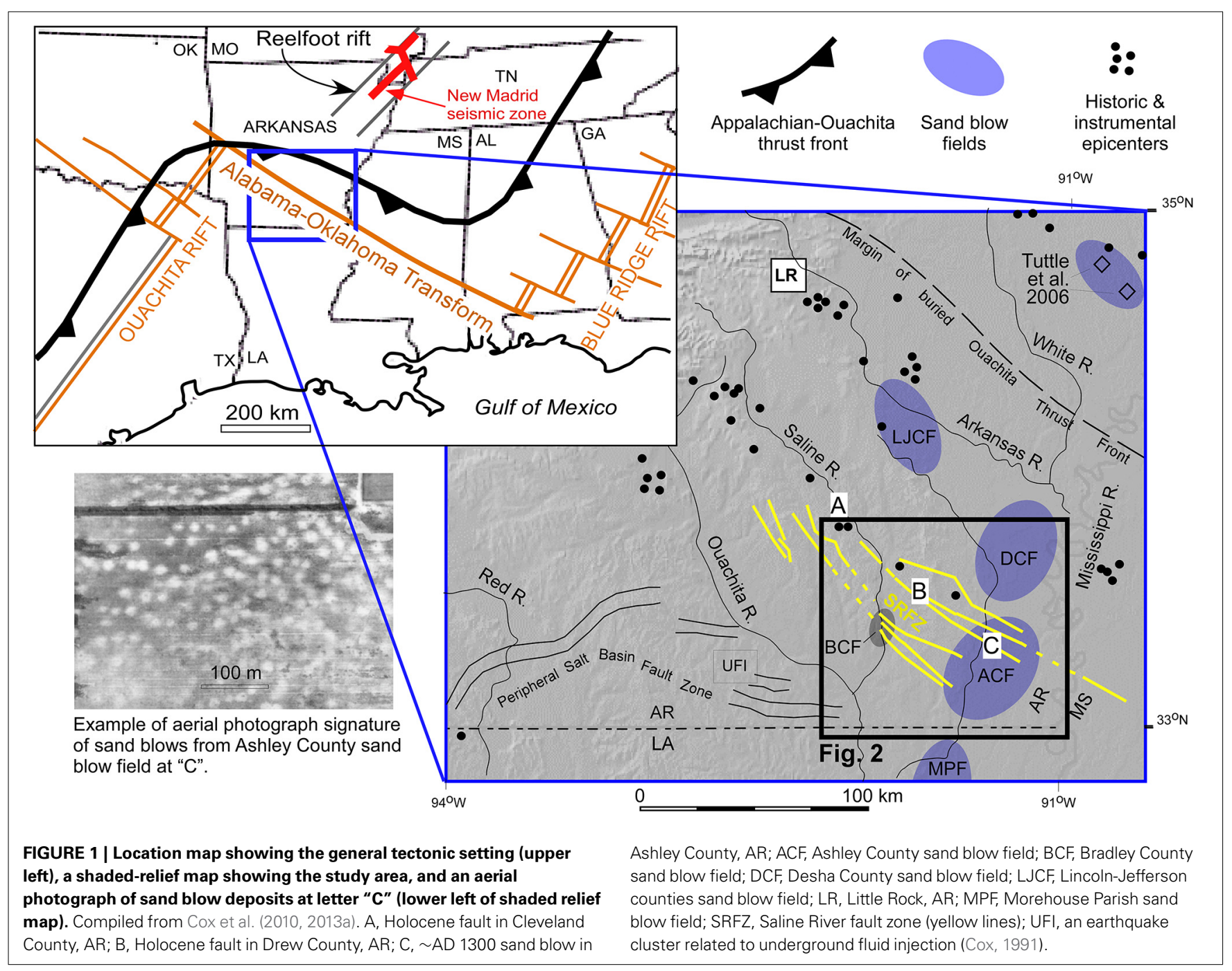

by the areal extent of light tonal anomalies (characteristic of sand blows on over-bank clay deposits) observed on aerial photography (e.g., Figure 1 photo inset). The mapped distribution of large-scale liquefaction features (sand blows) in southeast Arkansas is largely confined to Holocene alluvium of the former courses of the Arkansas River and tributaries where the blows are readily visible in agricultural fields (Figure 2A). Our previous trenching of these sand blows provide age constraints and show cross-cutting relationships that show a minimum of six earthquakes that triggered sand venting in the last 8000 years (Cox et al., 2004, 2007, 2010).

This project was conducted to investigate the Holocene limits and/or continuity of paleo-seismic liquefaction fields in southeast Arkansas by excavating stream bank alluvium and recording the presence or absence of liquefaction features between the previously mapped fields in areas that lack exposures of Holocene sediment and are obscured on aerial photography by forest cover. These results are a good example of the utility of small-scale liquefaction features for assessing paleoseismicity and bear upon estimates of paleo-earthquake magnitudes because they add field data that permit the reassessment of the size of liquefaction fields. Small-scale soft-sediment deformation caused by seismic shaking and liquefaction include clastic dikes and sills, detached blocks of a stratigraphic unit that are suspended in or foundered into an underlying layer that liquefied, and water escape features (dish structure) (Nichols et al., 1994; Owen, 1996; Counts and Obermeier, 2012; Sims, 2012; Tuttle and Hartleb, 2012). Seismic shaking and liquefaction cause convolution and pinch and swell of bedding, but these features can also be caused by sediment loading. In addition, soft-sediment deformation structures that are similar to liquefaction features can be caused by cryoturbation and lake impoundment (Brodzikowski and Haluszczak, 1987). We rule out these latter two processes for our study area because: (1) no Holocene cryoturbation has been reported in this region (Allen and Touchet, 1990; Aslan and Autin, 1998; Adelsberger and Kidder, 2007); and (2) no Holocene lacustrine sediments are mapped (Onellion, 1956; Larance et al., 1976) and we observed no lacustrine deposits at the sites displaying possible liquefaction.

\section{PREVIOUS INVESTIGATIONS}

Cox et al. (2000) previously documented Quaternary faulting in Drew County, AR (at "B" on Figure 1) by excavating trenches 


\section{A}

$92.3^{\circ} \mathrm{W}$
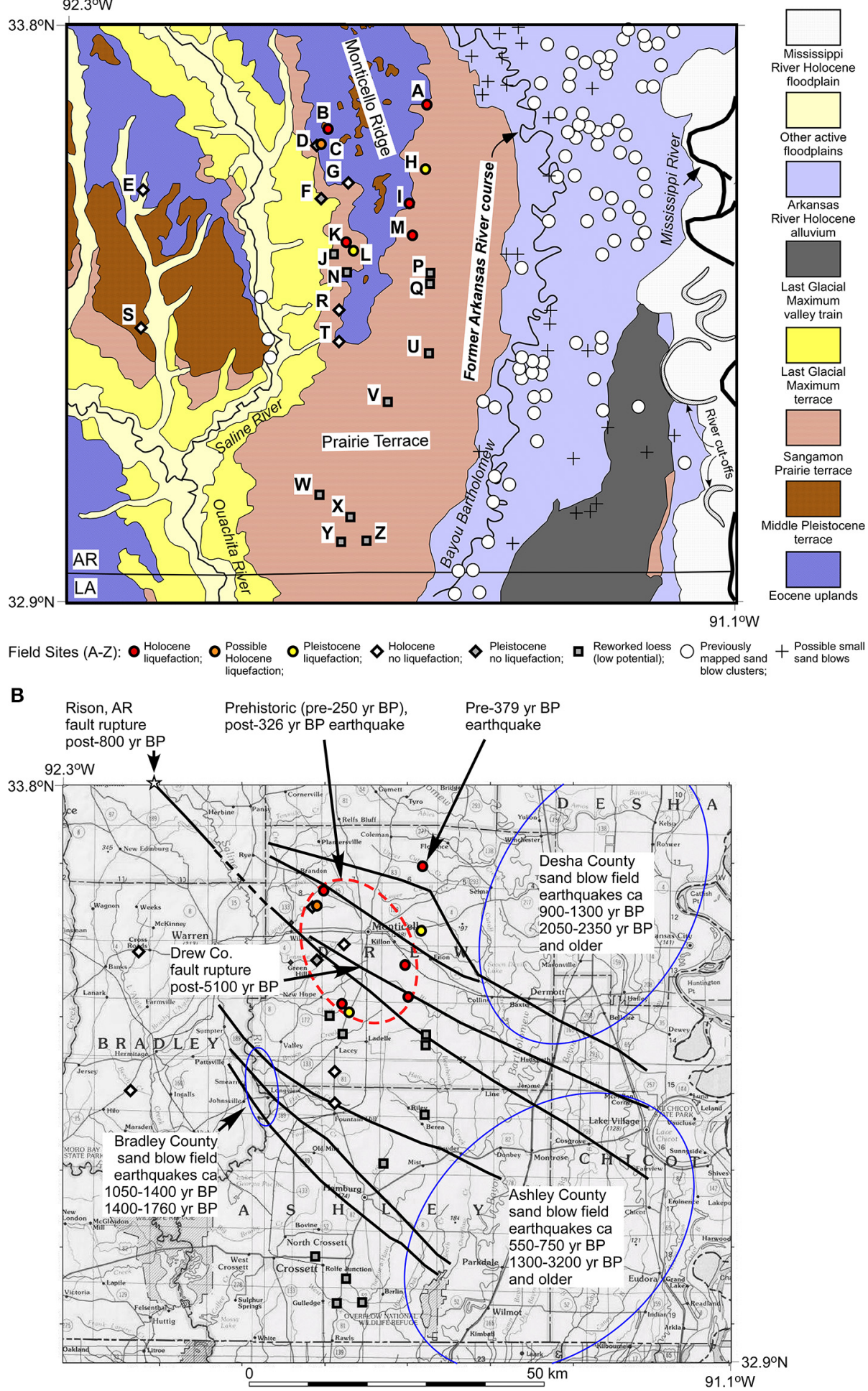

FIGURE 2 | (A) Geologic map of study area showing previously reported sand blow sites (Cox et al., 2004, 2007, 2010) and the 25 labeled field sites in this study (Table 1). A "Site O" designation was intentionally not used to avoid confusion with Holocene liquefaction sites. Geology compiled from Onellion
(1956), Bedinger and Reed (1961), and Saucier and Snead (1989). (B) Study area showing previously reported sand blow fields (Cox et al., 2004, 2007, 2010) and the mapped faults of the Saline River fault zone (heavy lines) (Cox et al., 2013a). 
across six surface faults within the Saline River fault zone: all faults displace marine Eocene units and fluvial Pleistocene units; movement on five post-dates Late Pleistocene loess (luminescence age $=23,600 \pm 3000$ year B.P.); and fault-tip folding on three faults deforms middle to late Holocene silt (luminescence age $=5100 \pm 600$ year B.P.). Additionally, Cox et al. (2000) documented trenches and road-cut exposures that revealed 30 meters of left-lateral strike-slip offset along the principal Saline River fault-zone shear plane since Late Pleistocene loess deposition. In Cleveland County, AR, (at "A" on Figure 1), $50 \mathrm{~km}$ northwest of the Cox et al. (2000) Drew County trench study, a faulted anticline exposed in a Saline River bank displaces $(1 \mathrm{~m})$ an organic-rich alluvial horizon with a ${ }^{14} \mathrm{C}$ age of $\mathrm{AD} 1398$ to $\mathrm{AD}$ 1157 (Cox et al., 2012). The anticline is topographically expressed as a prominent 1.3-km-long, 1-m-high linear ridge in Holocene alluvium that is collinear and continuous with a $1.5-\mathrm{km}$-long, $\leq 3$ m-high scarp that displaces Holocene and last glacial maximum Deweyville alluvial terraces. Eocene strata are displaced $80 \mathrm{~m}$ in the subsurface (Cox et al., 2012).

In southeast Arkansas, trenching of sand blows at eight sites near the Saline River fault zone provide age constraints and show cross-cutting) relationships that reveal at least six sand-venting earthquakes in the last 8000 years (Figure 12B) (Cox et al., 2004, 2007, 2010). Although a regional assessment by Tuttle and Hartleb (2012) ranks the evidence for seismically-triggered liquefaction in the region of southern Arkansas, northern Louisiana, and adjacent Mississippi as equivocal, sand blows in our study region satisfy most of the criteria listed in the Central and Eastern U.S. Paleoliquefaction Database. These criteria are as follows: (1) sand blows in this region are elliptical or circular in plain view; (2) blows are formed in clay-rich host deposits; (3) blows connect to feeder dikes below; (4) blow craters contain vented sand deposits that enclose clasts of host material (especially near the feeder dike) and are overlain by crater fill deposits; (5) vented sediment is fine to coarse sand that thins laterally away from the feeder dike; (6) blows are separated by layers of silty clay or clay that accumulated between earthquakes; and (7) localized downwarping of surface soil and host strata occurs near vents.

The south Arkansas sand blow fields (Figure 2) are not consistent with far-field liquefaction related to the New Madrid seismic zone because the fields are $\geq 150 \mathrm{~km}$ south of the southern-most sand blows known to have formed during the great earthquakes of AD1811-1812 in the New Madrid seismic zone and $>200 \mathrm{~km}$ south of the New Madrid seismic source faults. In addition, ages of south Arkansas liquefaction events do not correlate with the 1811-1812 earthquakes nor with a large penultimate New Madrid earthquake AD 1450 (Tuttle et al., 2002). An earlier large New Madrid earthquake AD 900 (Tuttle et al., 2002) occurred within the timeframe of the most recent paleo-earthquake in Desha County, Arkansas (Figure 12B). However, this AD 900 event is not listed in the liquefaction chronology of Tuttle et al. (2006) (Figure 1) for sand blows in eastern Arkansas (between the New Madrid seismic zone and the south Arkansas fields), and thus the Desha County event probably records a separate earthquake.

At one site in Ashley County (at "C" on Figure 1), $40 \mathrm{~km}$ southeast of the Drew County fault trenching site (at " $\mathrm{B}$ ") and $90 \mathrm{~km}$ southeast of the post-AD 1398 faulting in Cleveland
County (at "A"), ${ }^{14} \mathrm{C}$ dating of organic material filling a vent crater indicates that the most recent sand venting event was $\sim \mathrm{AD} 1300$ (Cox et al., 2004). If the Cleveland County faulting event caused the Ashley County liquefaction, the Ambraseys' (1988) empirical relationship of earthquake magnitude and greatest distance to liquefaction indicates that the liquefaction was caused by an M 7+ earthquake. In the sand blow fields of Ashley and Desha Counties, cone-penetration tests to a depth of $20 \mathrm{~m}$ measured shear-wave velocities, cone tip resistance, and sleeve friction in order to interpret stratigraphy and geotechnical properties (Cox et al., 2007). Together, these data indicate that ground accelerations $>0.5 \mathrm{~g}$ are needed to liquefy susceptible sediments and vent them to the surface through a clay layer that is $>5 \mathrm{~m}$ thick. These accelerations suggest near source shaking and an earthquake of approximately M 7 (Cox et al., 2007). However, following Ambraseys' (1988) empirical magnitude/distance relationship, the size of the fields as presently mapped suggest earthquake magnitudes of only about M 6. Our results herein bear upon the differences of these magnitude estimates.

\section{GEOLOGIC AND TECTONIC SETTING}

The study area is on the northern Gulf of Mexico coastal plain, an Atlantic-type passive margin that began forming with Triassic rifting during breakup of the continent of Pangea. Within the study area, Mesozoic/ Cenozoic sediment $2 \mathrm{~km}$ thick overlies rifted Paleozoic basement (Murray, 1961; Cushing et al., 1964; Salvador, 1991; Hosman, 1996). Initial rifting and graben development during the Mesozoic was aligned with a zone of lowercrustal weakness along the late Proterozoic Alabama-Oklahoma transform fault, on the southern edge of the North American craton (Figure 1) (Sawyer et al., 1991; Thomas, 2006; Cox et al., 2013a). Geophysical modeling of this deep Proterozoic cratonic margin shows it to be a sharp discontinuity (not typical of an extended transitional crust), suggesting that it is a transform fault (Mickus and Keller, 1992; Harry and Londono, 2004). Before Triassic rifting, thrust sheets were emplaced obliquely over the Alabama-Oklahoma transform margin during the late Paleozoic Ouachita orogeny (Thomas, 2006). Some rift faults were reactivated as strike-slip faults following Late Cretaceous uplift in south Arkansas accompanied by igneous activity (Cox et al., 2013a). Cenozoic sediments (Figure 2A) crop out in the study area, but exposure is poor. Exposures of the Saline River fault zone are the surface expression of a Cenozoic flower structure along the margin of the North American craton (Cox et al., 2000, 2012, 2013a).

Quaternary sediments unconformably overlie Eocene marine and marginal-marine strata (Wilbert, 1953; Onellion, 1956; Bedinger and Reed, 1961; Murray, 1961; Cushing et al., 1964; Hosman, 1996). Active floodplains are flanked by older Holocene terraces on rivers and major tributaries, and there are at least three Pleistocene fluvial terrace complexes (Deweyville, Prairie, and Intermediate Complex) (Saucier and Fleetwood, 1970; Saucier and Smith, 1986; Saucier and Snead, 1989; Saucier, 1994). The Deweyville terraces are of last glacial maximum age (35$12 \mathrm{ka}$ ), and Prairie terraces are last inter-glacial (Sangamon, 80-120 ka). Intermediate Complex terraces that cap Monticello Ridge (Figure 2A) are pre-Sangamon; their ages are poorly 
constrained as middle Pleistocene (Saucier and Snead, 1989) although their topographic position suggests that they may be Pliocene (Onellion, 1956). A veneer of last glacial maximum eolian silt (Peoria Loess) discontinuously covers the eastern study area, and a thin mid-Holocene eolian silt lies on some ridges (Follmer, 1996; Cox et al., 2000). Quaternary sediments in the study area that may contain liquefaction features include alluvium of the Ouachita and Saline rivers and their tributaries and tributaries, of Bayou Bartholomew (youngest abandoned course of the Arkansas River; Figure 1; Cox et al., 2013b). The banks of the Ouachita River and lower Saline River in the study area are under the waters of the Felsenthal Pool of the Ouachita River lock and dam system.

\section{INVESTIGATIONS UNDERTAKEN}

We conducted a field search for liquefaction features to assess the spatial and temporal extent of strong shaking in southeastern Arkansas. Our research questions were:

1. What is the geographic extent of Holocene liquefaction features in the study area?

2. What are the geographic extents of Holocene liquefaction features associated with individual paleo-earthquakes in the study area?

3. What were the magnitudes of these paleo-earthquakes?

4. What were the dates of these paleo-earthquakes?

In the field, we searched stream banks, located between the mapped extents of sand blow fields, for evidence of possible liquefaction in natural outcrops (rare) or excavated $1 \times 1 \mathrm{~m}$ faces in Holocene alluvium in stream banks. During progressive excavation we observed the three dimensional geometry of features. We described, sampled, and photographed the stratigraphy and any possible liquefaction features in each excavation or outcrop. Features we interpret as seismically-induced liquefaction sand dikes, sand sills, dish structures, and suspended blocks have sharp boundaries with host sediments. Care was taken to differentiate possible liquefaction features from redox boundaries associated with groundwater and soil moisture that do not correspond to depositional contacts or clastic intrusion contacts. Redox fronts and oxidized zones are common in these fluvial sediments, but they typically cross-cut sedimentary contacts and structures (see Sites A, I, K, and M, Figures 3, 5-7 for examples). We interpret cylindrical features filled with sediment from overlying strata as animal burrows or filled root cavities (see Sites B, K, and G, Figures 4, 6, 9 for examples).

We collected organic material from Holocene alluvium (including detrital charcoal and wood, and bulk soil O horizon samples) for accelerator mass spectrometry radiocarbon age analyses to provide age constraints on the timing of liquefaction events (Table 2). We also collected samples of fine-grained, quartz, fluvial point-bar sand in light-proof pipes for optical stimulated luminescence (OSL) age analyses (Table 3). Our OSL analyses followed the protocol previously used successfully in Holocene fluvial sediments in the studies of Thomas et al. (2007) and Stamm et al. (2013). No earthquakes strong enough to cause liquefaction have been felt since the region was settled circa $\mathrm{AD}$
1750, and thus we use this as our minimum age constraint for liquefaction when we do not have a minimum-age constraint that is older than AD 1750.

We investigated 25 sites (Figure 2 and Table 1 ) and looked for small-scale features formed by liquefaction of unconsolidated sediments (e.g., Nichols et al., 1994; Owen, 1996; Ross et al., 2011; Counts and Obermeier, 2012; Sims, 2012). Holocene and Pleistocene alluvium were discriminated in the field on the basis of degree of weathering and induration (both are significantly greater in Pleistocene alluvium). Below in "Results," we describe sites shown on Figure 2 that display Holocene or Pleistocene liquefaction features, as well as examples of sites that display stratified Holocene sand/gravel alluvium without evidence of liquefaction for comparison.

\section{RESULTS}

Holocene alluvial deposits of streams draining the Pleistocene (Sangamon) Prairie terrace in the southern and southeastern parts of the study area (Sites P, Q, U, V, W, X, Y, and Z, Figure 2A and Table 1 ) are composed of poorly stratified silt and clay mud that has been reworked from the 4- to 5-m-thick loess cap on the terrace surface. In the downstream reaches of tributaries that receive backwater flow from larger rivers during flooding, the sediments are characterized by poorly stratified silt and clay alluvium, presumably deposited during backwater flooding (e.g., Sites $J$ and N, Figure 2 and Table 1). Due to the low liquefaction potential of mud overlying partially indurated Pleistocene and Eocene sediments and the absence of stratification at these sites, we cannot interpret our lack of observation of liquefaction features as evidence of a lack of ground shaking. For this reason, we designate these sites as "Reworked loess" rather than "Holoceneno liquefaction" on Figure 2. Results of radiocarbon and OSL age analyses are given in Tables 2, 3 and shown on Figure 3 through Figures 10, 12.

At our field sites in the central and upstream reaches of streams that drain areas with sand-and-gravel-bearing Eocene and Pleistocene substrates, Holocene alluvium is composed of stratified, unconsolidated gravel, sand, silt, and clay that we assess as having high liquefaction potential. The geographic relationship of our field sites containing liquefaction features to previously mapped sand blows is shown on Figure 2. Features we observed at some sites that we interpret as evidence for liquefaction include sand dikes and intrusions, convoluted or disrupted beds, blocks of one horizon suspended within another horizon that liquefied, and water-escape "dish" structure (Table 1). We also interpret swelling and pinching of the thickness of sand horizons as possible evidence of liquefaction, being aware that rapid sediment loading in river channels and lakes can result in structures that are superficially similar to seismically-triggered liquefaction features (Brodzikowski and Haluszczak, 1987; Selker, 1993; Owen, 2003). These loading structures include protrusions and detached bulbs of sand (load casts) forced into an underlying clay bed, protrusions of clay (flame structures) into an overlying sand bed, and pinch and swell of underlying beds. However, load casts differ from the suspended blocks we describe here because we observe blocks of an underlying bed that have been transported upward within a discordant intrusive body of sand, or 

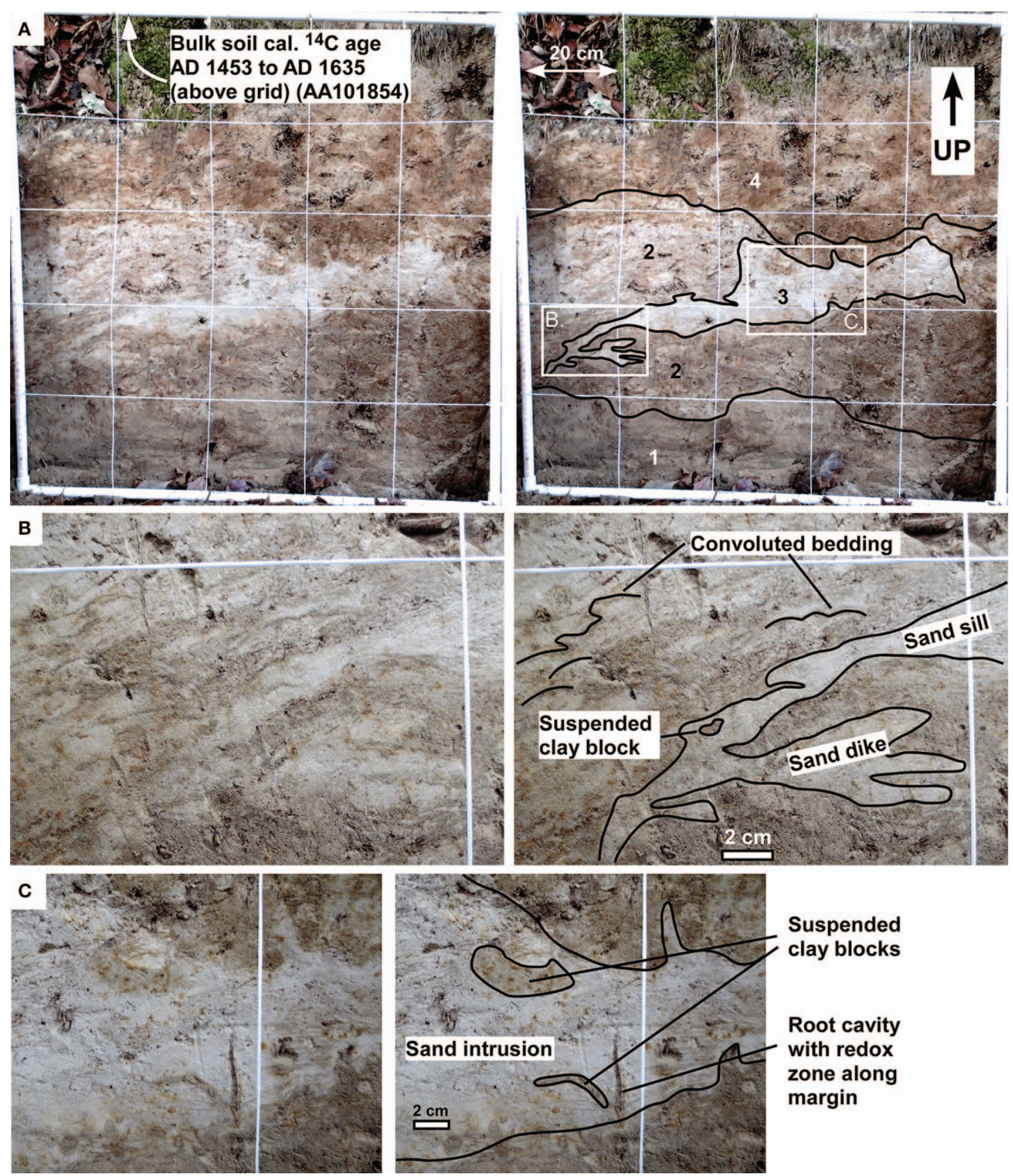

FIGURE 3 | Site A (Upper Cutoff Creek; $33.72764^{\circ} \mathrm{N}, 9^{1.68954^{\circ}}$ W)-Top is up. Locations of $(\mathbf{3 B}, \mathbf{C})$ are shown on (3A). (A) Uninterpreted photograph (left) and interpreted photograph (right) of $1 \times 1 \mathrm{~m}$ grid on vertical excavation showing small-scale bedding irregularities interpreted to be caused by liquefaction during ground shaking. Unit 1, Upper Cutoff Creek channel, massive fine to medium sand; Unit 2, Convoluted Upper Cutoff Creek point-bar, $0.5-1.0 \mathrm{~cm}$ interbeds of sandy clay and fine to medium sand; Unit 3, Structureless intrusion of fine sand with sharp contacts; Unit 4, Upper Cutoff Creek overbank, massive to poorly bedded, sandy loam (cumulative? A soil horizon). Soil horizons above this grid are not disrupted, and we interpret the bulk soil ${ }^{14} \mathrm{C}$ age from Sample AA101854 (collected $78 \mathrm{~cm}$ above grid) to post-date liquefaction. Thus, it places a minimum age of AD 1635 on the triggering paleo-earthquake. (B) Photograph details showing a sand dike, sand sills, a suspended clay block, and convoluted bedding. (C) Photograph details showing a sand dike containing suspended clay blocks. we observe blocks of clay that have settled into underlying sand, rather than sand bulbs forced into underlying clay. Flame structures differ from the sand dikes we describe here because we do not observe upward protrusions of clay. Furthermore, both load cast and flame structures typically show systematic asymmetry with the tops of the protrusions displaced in a down-current direction (Cole, 1977); we do not observe systematic asymmetries in the features we interpret as suspended blocks, sand dikes, 


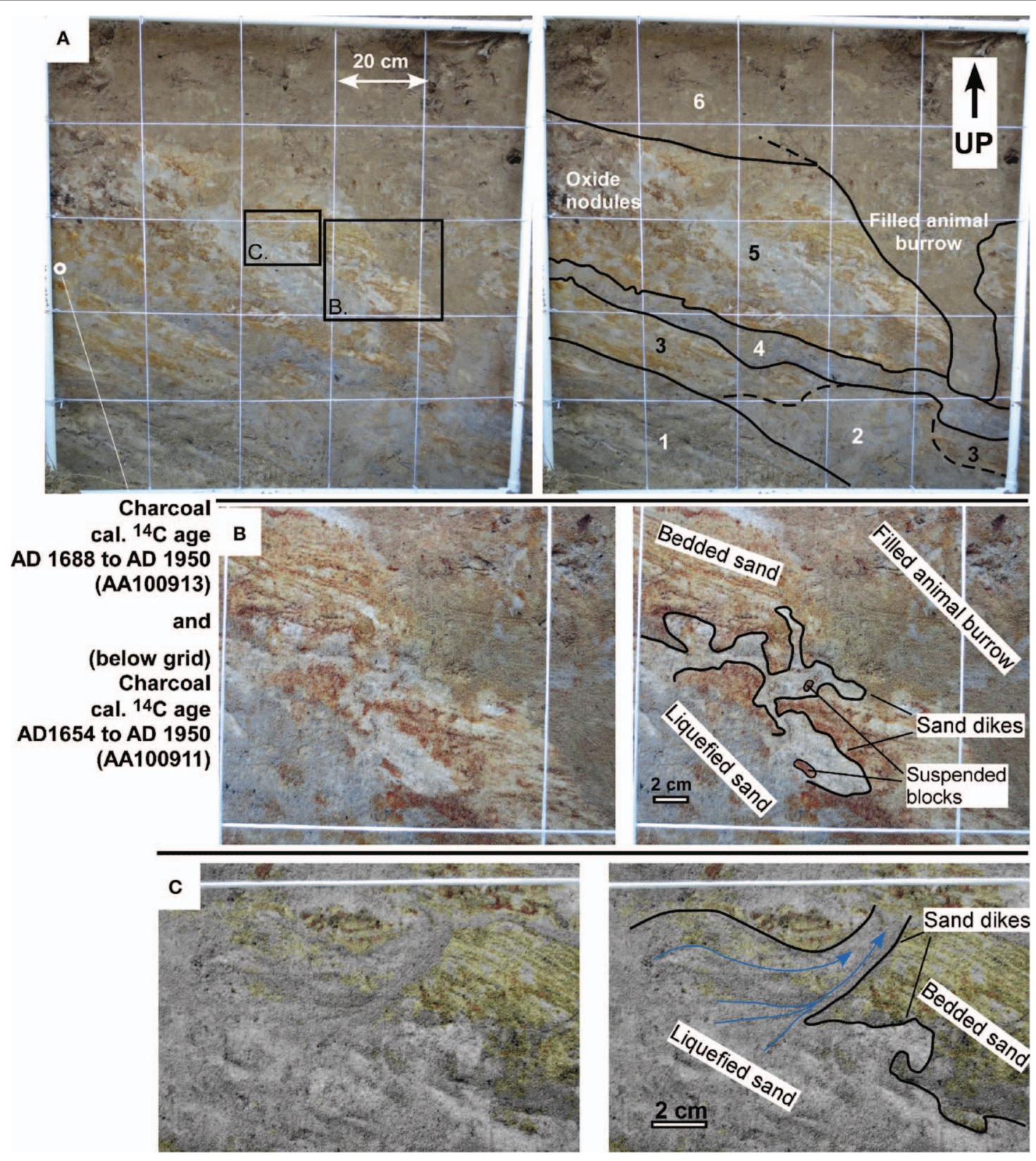

FIGURE 4 | Site $B$ (Hungerrun Creek; $33.69237^{\circ} \mathrm{N}, 91.87181^{\circ} \mathrm{W}$ ) - Top is up. Locations of (B,C) are shown on (A). (A) Uninterpreted (left) and interpreted (right) photograph of $1 \times 1 \mathrm{~m}$ grid of vertical excavation showing small-scale bedding irregularities interpreted to be caused by ground shaking and liquefaction. Unit 1, Hungerrun Creek channel, medium-bedded coarse sand and gravel; Unit 2, Structureless (liquefied?) fine/medium sand; Unit 3, Hungerrun Creek point-bar, medium-bedded fine sands; Unit 4, Hungerrun Creek point-bar, massive clay-rich fine sand; Unit 5, Convoluted Hungerrun
Creek point-bar, thin-bedded fine sand and internal sand dike intrusions; Unit 6. Hungerrun Creek overbank, massive loam (aggraded A soil horizon). We interpret the detrital charcoal ${ }^{14} \mathrm{C}$ ages from Samples AA100911 and AA100913 to pre-date liquefaction, and thus they place a maximum age of AD 1688 on the triggering paleo-earthquake. (B) Photograph details showing liquefied sand intruding thin-bedded sand (C) Photograph details showing liquefied sand with a fabric indicating flow (blue arrows) into small-scale sand dikes cutting thin-bedded sand suggesting water escape. or dish structure. In a stratigraphic fluvial sand horizon that lacks evidence of being liquefied (it contains bedding) and does not intrude other horizons, we interpret suspended blocks of an underlying bed as rip-up clasts produced by scouring (see Site $\mathrm{T}$ for an example) rather than blocks suspended in seismically liquefied sand.
At our field sites A, B, I, K, M, and possibly C, we interpret deformation features in the alluvial strata as liquefaction evidence of strong Holocene ground shaking that pre-dates settlement about AD 1750. At Sites B, C, I, and K, our radiocarbon data place maximum age constraints on liquefaction events at $<$ at after AD 1200 (Table 2). Site M has a maximum radiocarbon age 


\section{Charcoal cal. ${ }^{14} \mathrm{C}$ age \\ AD 1680 to AD 1950 (AA100917)}

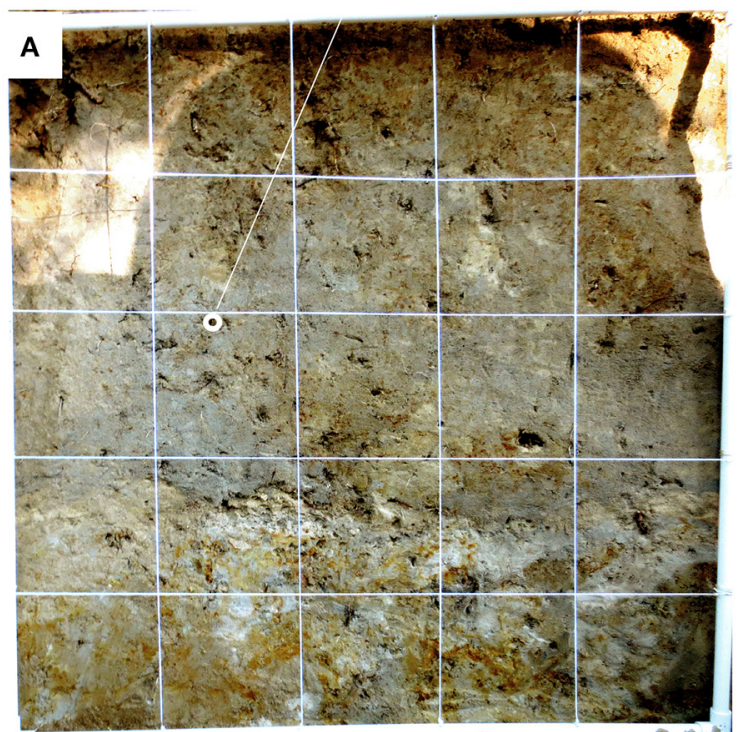

(Below grid) Charcoal cal. ${ }^{14} \mathrm{C}$ age AD 1229 to AD 1443 (AA101852)

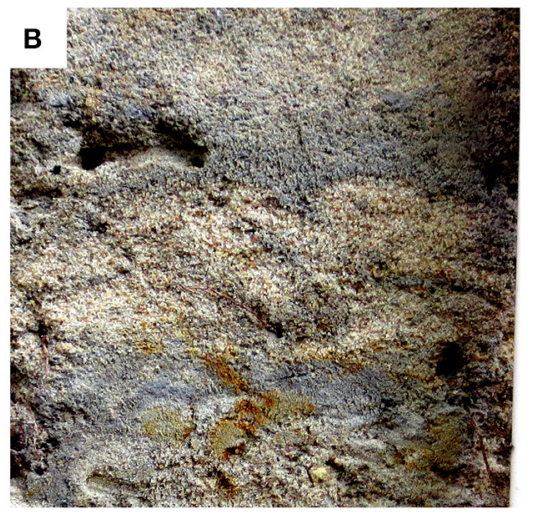

FIGURE 5 | Site I (Sandy Creek, $33.57962^{\circ} \mathrm{N}, \mathbf{9 1 . 7 2 2 4 1}^{\circ} \mathrm{W}$ ) - Top is up. Location of (B) is shown on (A). (A) Uninterpreted photograph (left) and interpreted photograph (right) of $1 \times 1 \mathrm{~m}$ grid on vertical excavation showing convoluted bedding and pinch-swell features in Units 2 and 3 interpreted to be caused by ground shaking and liquefaction. Unit 1, Sandy Creek overbank, massive sandy clay; Unit 2, Convoluted Sandy Creek channel,

medium-bedded gravel; Unit 3, Convoluted Sandy Creek point-bar,

medium/thin interbedded clay and sand; Unit 4, Sandy Creek overbank,
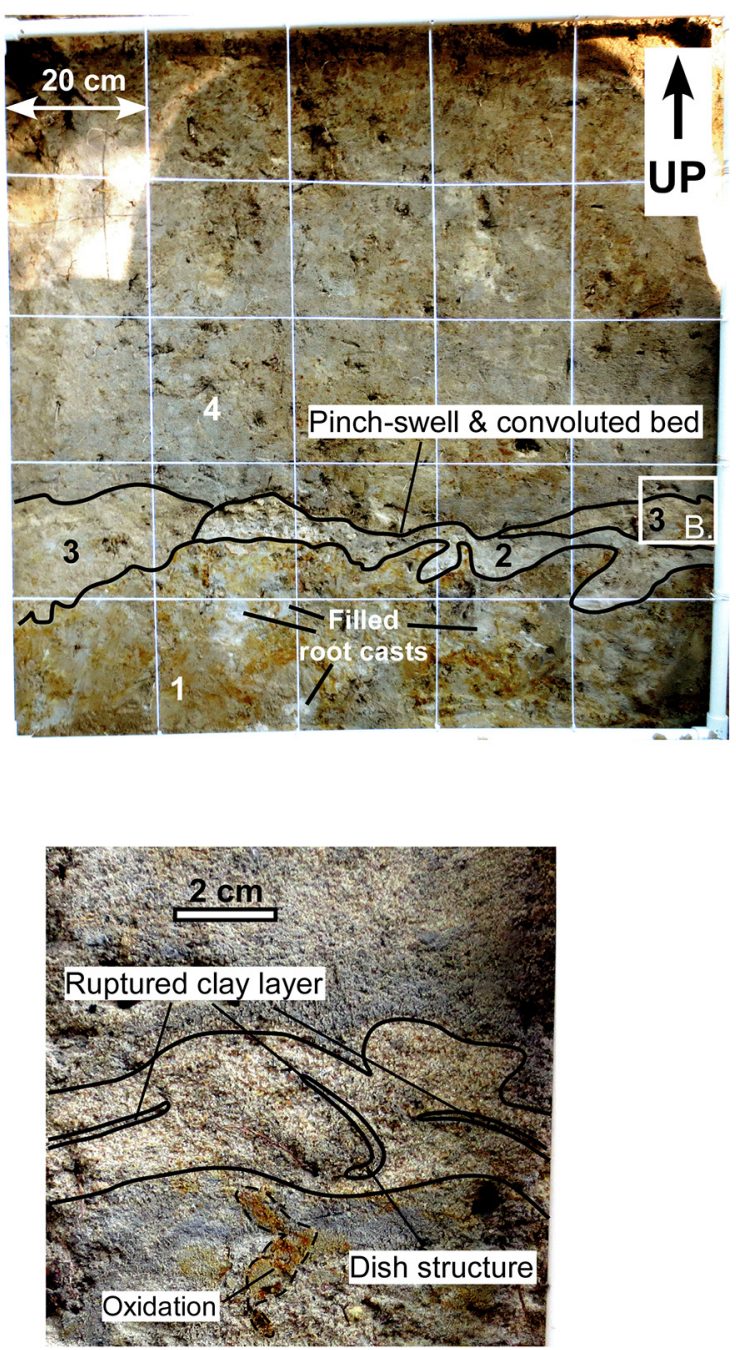

massive loam (aggraded A soil horizon). We interpret the detrital charcoal ${ }^{14} \mathrm{C}$ age from Sample AA101852 to pre-date liquefaction, and thus it places a maximum age of AD 1229 on the triggering paleo-earthquake. The detrital charcoal ${ }^{14} \mathrm{C}$ age of Sample AA100917 may post-date liquefaction but does not constrain the triggering paleo-earthquake to before the historic period (our minimum constraint). (B) Photograph details showing small-scale convoluted beds and dish structure suggesting water escape. "Oxidation" denotes reddening of the sediment caused by weathering of iron-bearing minerals.

constraint that places liquefaction as after 1410 BC. Site A has a minimum radiocarbon age constraint that places liquefaction before $\mathrm{AD} 1635$, but no maximum age constraint is available.

At Sites A, B, I, K, and M, we observed well stratified Holocene sand and clay disrupted by sand intrusions, convoluted beds, pinch and swell of bedding, clay blocks suspended in sand, and sand and clay disrupted by dish structures indicative of water escape (Figure 3 through Figure 7). Site K (Figure 6) contains prominent soft-sediment deformation where we observed well stratified Holocene point-bar sand (Units 4 and 5) and overbank loam (Unit 7) disrupted by NE-striking, planar, clastic dikes up to
$20 \mathrm{~cm}$ wide and a clastic intrusion $60 \mathrm{~cm}$ wide (Unit 6). We also observed a suspended block of Unit 5 , transported upward within the intrusion, a foundered block of Units 4 and 5, small-scale convoluted bedding (Figure 6B), and pinch and swell of Units 2 and 3 . We interpret the features at Site $\mathrm{K}$ as the result of seismicallyinduced liquefaction. Although Units 2 and 3 at Site K show no protrusions or flow fabrics that would indicate forced injection, their structureless texture suggests that they may be in situ fluvial beds that liquefied during an earthquake that triggered the injection of Unit 6 . Furthermore, the lateral extension of Unit 4 may record lateral spreading during seismic shaking. 


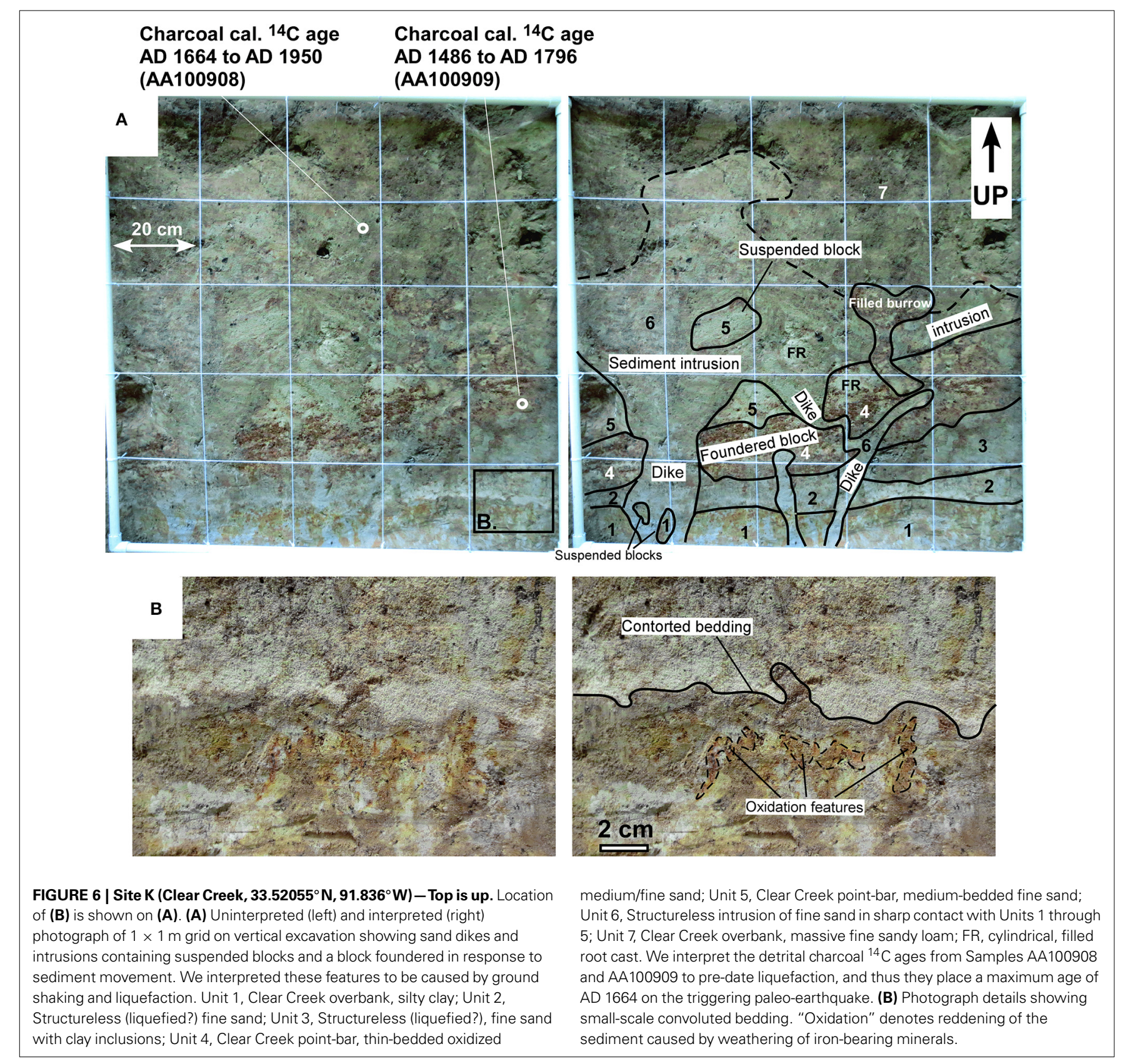

At site A, a sand intrusion (Unit 3) cross-cuts point-bar bedding of Unit 2 and contains suspended clay blocks of the host, and Unit 2 displays convoluted internal bedding (Figure 3). We interpret these features as the result of seismically-induced liquefaction. The geometry and texture of Unit 3 suggests that its source was Unit 1, but we did not observe a direct connection between the two units.

At Site B, we interpret sand intrusions with flow fabric that cross-cut point-bar bedding within Unit 5 as seismicallyinduced liquefaction (Figure 4). Although Unit 2 lacks protrusions and flow fabric indicative of forced injection, it lacks internal structure and cross-cuts bedded point-bar sand of Unit 3, suggesting Unit 2 may have been forcefully injected. An animal burrow filled from above by bioturbated sandy loam (Unit 6) at Site B is not of seismic origin.

At Site I, we observed pinch-swell features in Units 2 and 3 and convoluted bedding contacts between Units 1 through 4 (Figure 5). Filled root casts in Unit 1 do not correspond to bedding convolutions and thus can be ruled out as their cause. Unit 3 contains dish structure that suggests strong, sudden water escape. We interpret these features as the result of seismically-induced liquefaction.

At Site C, we observed stratified gravel, sand, and clay Holocene channel and point-bar alluvium (Figure 8) deformed by down-warping and small-scale pinch and swell of beds in the 


\section{Wood cal. ${ }^{14} \mathrm{C}$ age Bulk soil cal. ${ }^{14} \mathrm{C}$ age $1410 \mathrm{BC}$ to $930 \mathrm{BC}$ and (above grid) post- $A D 1950$ (AA100918) (AA101853)}
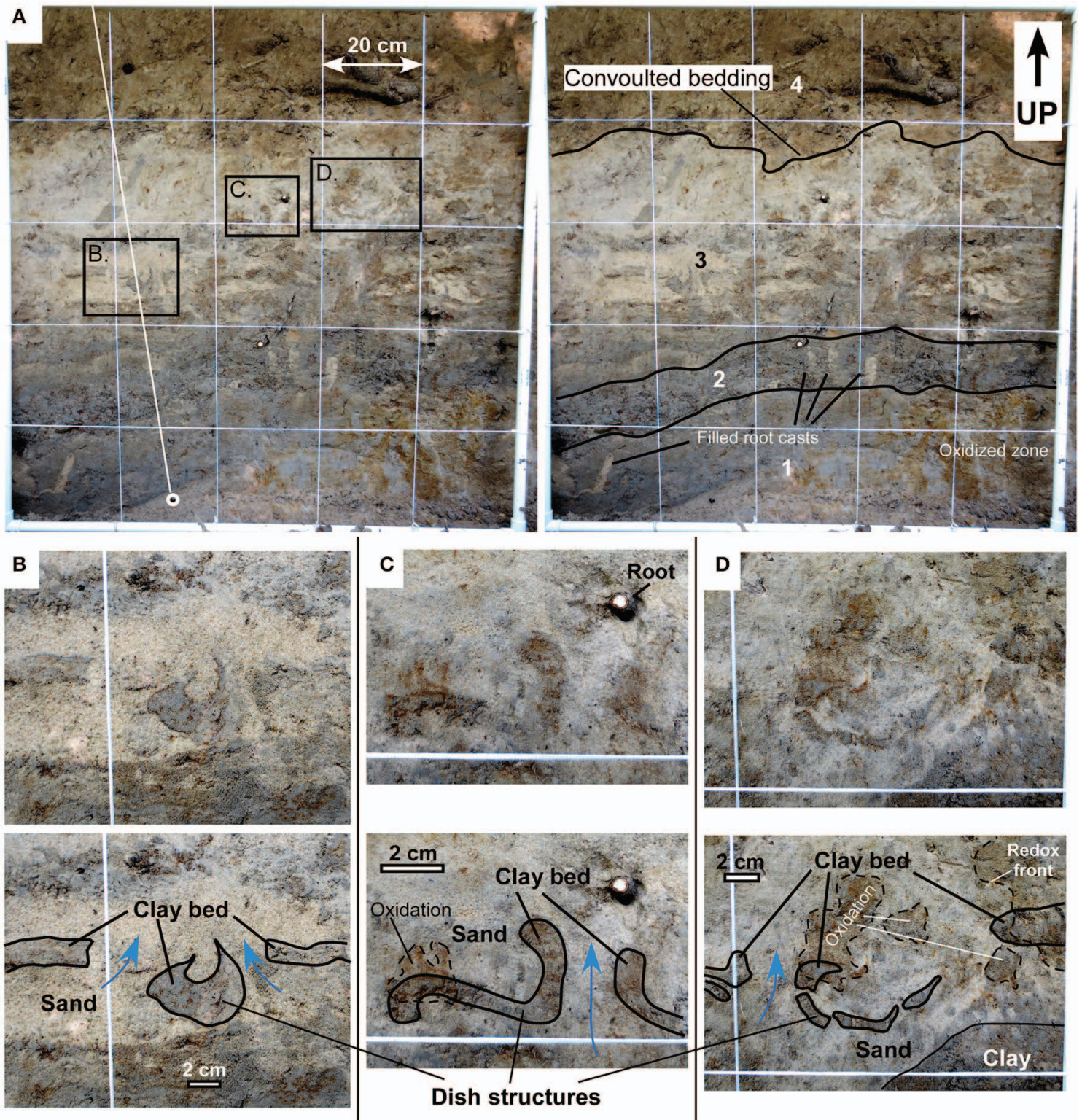

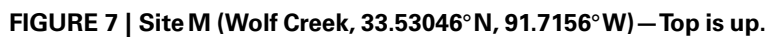

Locations of (B-D) are shown on (A). (A) Uninterpreted photograph (left) and interpreted photograph (right) of $1 \times 1 \mathrm{~m}$ grid on vertical excavation showing small-scale bedding irregularities interpreted to be caused by ground shaking and liquefaction. Unit 1, Wolf Creek overbank, massive clay; Unit 2, Wolf Creek point-bar, medium-bedded sandy clay; Unit 3, Convoluted Wolf Creek point-bar, medium interbeds of fine sand and clay; Unit 4, Wolf Creek overbank, massive loam (aggraded A soil horizon). We interpret the detrital wood ${ }^{14} \mathrm{C}$ age from Sample AA100918 to pre-date liquefaction, and thus it places a maximum age of $1410 \mathrm{BC}$ on the triggering paleo-earthquake. The bulk soil ${ }^{14} \mathrm{C}$ age from Sample AA101853 (collected $1 \mathrm{~m}$ above grid) post-dates liquefaction but does not constrain the triggering paleo-earthquake to before the historic period (our minimum constraint). (B) Photograph details showing individual clay bed deformed by fluid-escape "dish" structure. (C) Photograph details showing individual clay bed deformed by fluid-escape "dish" structure. (D) Photograph details showing individual clay bed deformed by fluid-escape "dish" structure. Blue arrows denote direction of flow. "Oxidation" denotes reddening of the sediment caused by weathering of iron-bearing minerals. lower right-hand part of our grid, suggesting possible liquefaction due to ground shaking at this site. Alternatively, because we observed no features characteristic of rapid water escape, the deformation at Site $\mathrm{C}$ may be due to sediment loading.
Our interpretation of the above features as a record of earthquake-induced liquefaction is consistent the criteria for earthquake-induced liquefaction features listed in Tuttle and Hartleb (2012). Suspended blocks that have been transported 

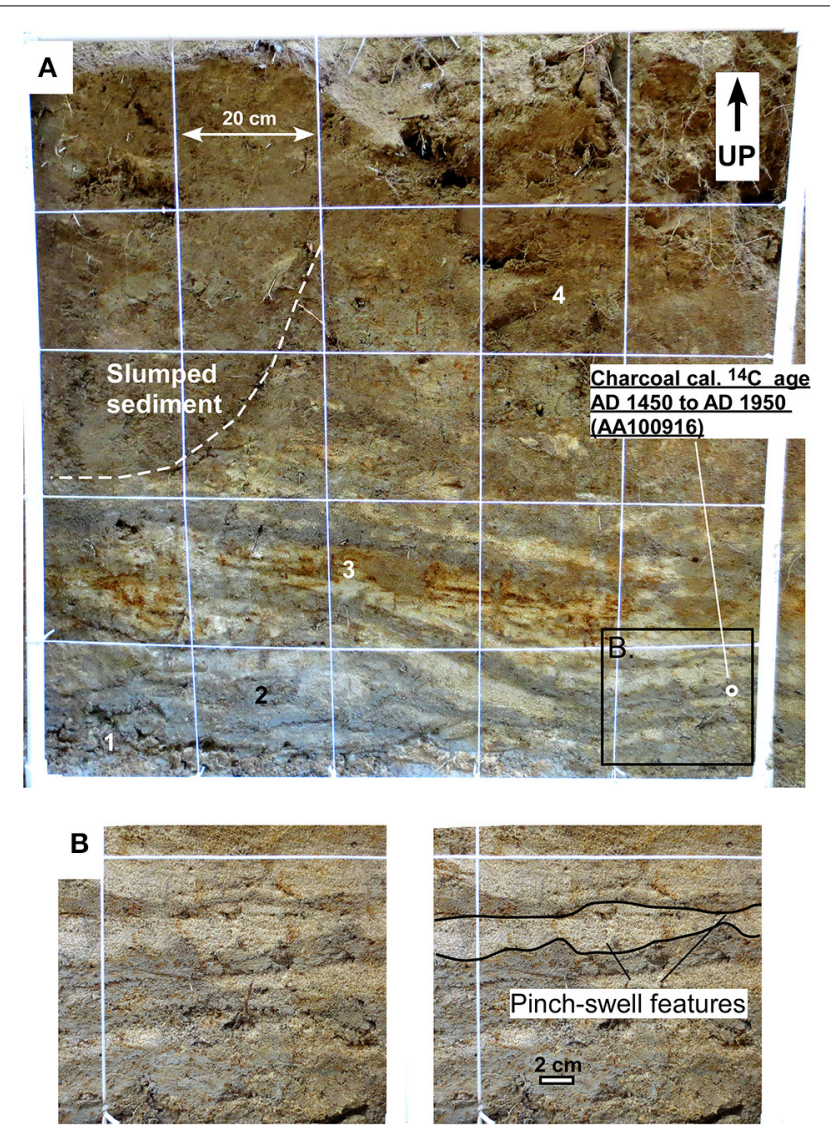

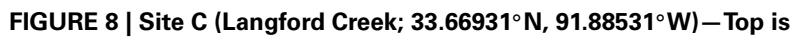
up. Location of (B) is shown on (A). Photograph of possible small liquefaction features in Holocene sediment. (A) $1 \times 1 \mathrm{~m}$ grid on vertical excavation. Unit 1, Langford Creek channel, medium-bedded gravel; Unit 2, Langford Creek, point-bar, medium interbeds of fine sand and clay; Unit 3, Langford Creek, point-bar, medium-bedded fine sands with minor clay lenses; Unit 4, Overbank, massive loam (aggraded A soil horizon). We interpret the detrital charcoal ${ }^{14} \mathrm{C}$ age from Sample AA100916 to pre-date possible liquefaction, and thus it places a maximum age of $A D$ 1450on the inferred triggering paleo-earthquake. (B) Photograph details showing minor pinch-swell features. Alternatively, this deformation may be due to sediment loading.

upward and water-escape structures at Sites B, I, K, and M are indicative of sudden, strong, upwardly directed hydraulic force of short duration. These hydraulic conditions would not develop under non-seismic conditions because the fluvial sedimentary units containing the liquefaction features are confined to low-relief valleys ( $<20 \mathrm{~m} / \mathrm{km}$ slope) insufficient to produce high hydraulic head on the surface aquifer. Sites A, B, I, K, and M show more than one type of liquefaction feature and similar features are found at Sites A, B, and K (sand dikes), Sites B, I, and M (waterescape structures), Sites A, K, and $M$ (suspended blocks), and Sites A, B, I, and M (convoluted bedding). The age data report herein together with previously reported ages (Cox et al., 2000, 2004, 2007, 2010, 2012) support contemporaneous and episodic formation of features over a large area.

We did not observe evidence of liquefaction in sandy Holocene strata at sites E, G, R, S, and T. Deposition of sediments at Sites R

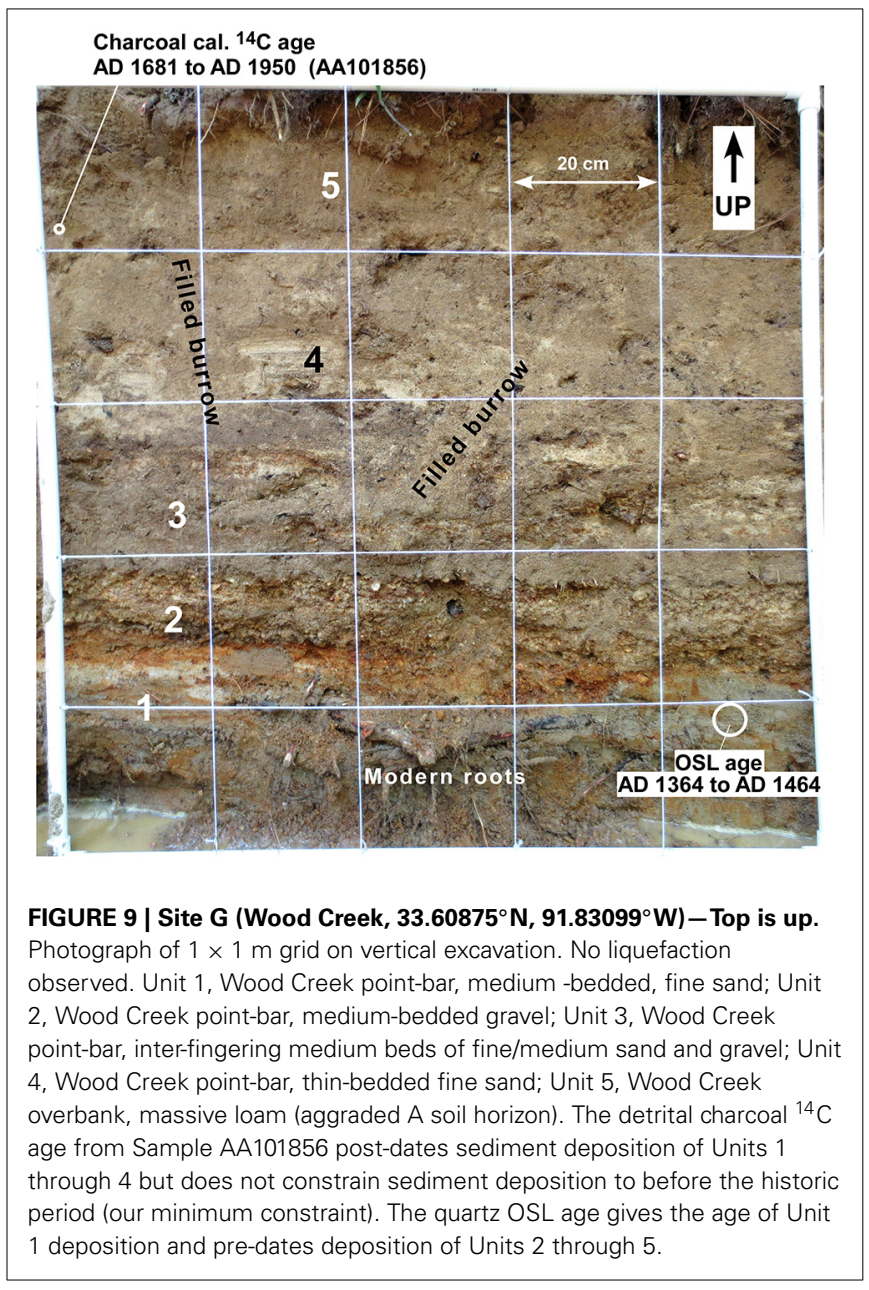

and S have minimum radiocarbon age constraints of AD 1393 and AD 1630, respectively, and sediments at Sites $G$ and $T$ have maximum OSL age constraints of AD 1364 and AD 1564 years B.P., respectively. No age data are available at Site E. Non-seismogenic bioturbation features (cylindrical animal burrows and root casts filled from overlying sedimentary units) cross-cut the stratigraphy at several of these sites. At Site G, thin beds of sandy point-bar alluvium are heavily burrowed (Units 3 and 4, Figure 9), and burrows are filled with overbank loam derived from Unit 5. We observed no liquefaction features, but disruption of the sandy, liquefiable strata by burrowing may have obscured small-scale liquefaction features such as dish structures. At Site T (Figure 10), Unit 2 pinches out to the right in our grid, but we interpret this as the margin of a small, filled paleo-channel rather than a pinchand-swell liquefaction feature because its internal stratigraphy is not deformed. We interpret several small clay bodies within Unit 2 as rip-up clasts of Unit 1 that were incorporated during scour of the paleo-channel floor rather than as blocks suspended in sand that liquefied.

At two sites ( $\mathrm{H}$ and $\mathrm{L}$ ), we found evidence suggesting liquefaction of Pleistocene alluvium. On a vertical wall of a sand mine in the Prairie terrace $(80-120 \mathrm{ka})$ at Site $\mathrm{H}$, we observed convoluted bedding in well stratified, weakly indurated fluvial 
Table 1 | Field site descriptions.

\begin{tabular}{|c|c|c|c|c|c|c|}
\hline Site & $\begin{array}{l}\text { Latitude (N)/ } \\
\text { Longitude (W) }\end{array}$ & Setting & Alluvium & Age & $\begin{array}{l}\text { Liquefaction } \\
\text { potential }\end{array}$ & Liquefaction features \\
\hline A & $33.72764 / 91.68954$ & Upper Cutoff Cr bank & Bedded clay, sand & Holocene & High & $\begin{array}{l}\text { Sand intrusions, convoluted } \\
\text { beds, suspended blocks }\end{array}$ \\
\hline $\mathrm{B}$ & $33.69237 / 91.87181$ & Hungerrun $\mathrm{Cr}$ bank & Bedded sand, gravel & Holocene & High & $\begin{array}{l}\text { Sand intrusions, flow fabric, } \\
\text { convoluted beds, pinch/swell } \\
\text { features }\end{array}$ \\
\hline C & $33.66931 / 91.88531$ & Langford Cr bank & Bedded sand, gravel, clay & Holocene & High & $\begin{array}{l}\text { Down-warped beds(?), minor } \\
\text { pinch/swell features }\end{array}$ \\
\hline $\mathrm{D}$ & $33.66856 / 91.88625$ & Langford Cr bank & Massive sand & Middle Pleistocene & High & None \\
\hline$E$ & $33.60326 / 92.2050$ & Steepbank L'Aigle Cr bank & Massive and bedded sand & Holocene & High & None \\
\hline $\mathrm{F}$ & $33.58621 / 91.88271$ & Tenmile Cr bank & Massive clay-rich sand & Middle Pleistocene & Moderate & None \\
\hline G & $33.60875 / 91.83099$ & Wood Cr bank & Bedded sand, gravel & Holocene & High & None \\
\hline $\mathrm{H}$ & $33.62406 / 91.7003$ & Sand pit in Prairie Terrace & Bedded sand & Late Pleistocene & High & Convoluted beds \\
\hline I & $33.57962 / 91.72241$ & Sandy Cr bank & Bedded sand, gravel, clay & Holocene & High & $\begin{array}{l}\text { Convoluted beds, dish } \\
\text { structure, pinch/swell } \\
\text { features }\end{array}$ \\
\hline$J$ & $33.50228 / 91.86095$ & Clear Cr bank & Reworked loess & Holocene & Low & None \\
\hline K & $33.52055 / 91.8360$ & Clear Cr bank & Bedded clay, sand & Holocene & High & $\begin{array}{l}\text { Sand dikes, foundered block, } \\
\text { suspended blocks }\end{array}$ \\
\hline $\mathrm{L}$ & $33.50916 / 91.82417$ & Clear Cr bank, south fork & Bedded sand, gravel, clay & Middle Pleistocene & High & $\begin{array}{l}\text { Sand dikes, convoluted } \\
\text { beds, pinch/swell features, } \\
\text { suspended blocks }\end{array}$ \\
\hline$M$ & $33.53046 / 91.7156$ & Wolf Cr bank & Bedded clay, sand & Holocene & High & $\begin{array}{l}\text { Convoluted bedding, dish } \\
\text { structure, suspended blocks }\end{array}$ \\
\hline $\mathrm{N}$ & $33.47324 / 91.83442$ & Brown $\mathrm{Cr}$ bank & Reworked loess & Holocene & Low & None \\
\hline$P$ & $33.47548 / 91.68587$ & Lost Cr bank & Reworked loess & Holocene & Low & None \\
\hline Q & $33.45847 / 91.68493$ & Bearhouse $\mathrm{Cr}$ bank & Reworked loess & Holocene & Low & None \\
\hline $\mathrm{R}$ & $33.41774 / 91.84886$ & Panther $\mathrm{Cr}$ bank & Bedded silt, gravel, clay & Holocene & High & None \\
\hline $\mathrm{S}$ & $33.39285 / 92.2244$ & Beech Cr bank & Massive clay, sand & Holocene & High & None \\
\hline $\mathrm{T}$ & $33.36869 / 91.85048$ & Flat Cr bank & Bedded sand, gravel, clay & Holocene & High & None \\
\hline U & $33.35026 / 91.68557$ & Griswould Cr bank & Reworked loess & Holocene & Low & None \\
\hline V & $33.27783 / 91.76244$ & Chemin-a-haut Cr bank & Reworked loess & Holocene & Low & None \\
\hline W & $33.13543 / 91.8852$ & West Cr bank & Reworked loess & Holocene & Low & None \\
\hline$x$ & $33.10543 / 91.82981$ & Hanks Cr bank & Reworked loess & Holocene & Low & None \\
\hline Y & $33.0652 / 91.84613$ & West Cr bank & Reworked loess & Holocene & Low & None \\
\hline Z & $33.06733 / 91.7990$ & Hanks Cr bank & Reworked loess & Holocene & Low & None \\
\hline
\end{tabular}

sand beneath $4 \mathrm{~m}$ of silty clay weathered Peoria loess dating from the last glacial maximum. We interpret these convoluted beds as liquefaction features formed in response to strong shaking. The liquefaction probably occurred during the Pleistocene because these sediments now have a low to moderate liquefaction potential due to weak induration and we did not observe sand intrusions in the Peoria loess. Root casts filled with reworked loess cross-cut the stratigraphy but are unrelated to the convoluted bedding (see Cox et al., 2013b, Figure 17 for Site H photographs). At a natural outcrop of moderately indurated Middle Pleistocene alluvium (Intermediate Complex of Saucier and Snead, 1989) on the South Fork of Clear Creek (Site L), we observed sand dikes, convoluted beds, suspended blocks, and pinch and swell of beds (Figure 11). These features also suggest liquefaction in response to strong earthquakes during the Pleistocene before the sediments became indurated. The ENE-WSW strike of the sand dikes is consistent with jointing in response to the
ENE-WSW Quaternary compressive stress field of the eastern United States (Zoback, 1992). Massive Pleistocene alluvium at Sites D and F is not stratified well enough for us to evaluate liquefaction.

\section{DISCUSSION}

We found evidence for Holocene liquefaction that we interpret as resulting from strong ground shaking at five sites (A, B, I, K, and M; Table 1 and Figure 2) and possibly at Site C. In addition, we observed evidence for Pleistocene liquefaction at Sites $\mathrm{H}$ and L. Because all these sites are clustered near Pleistocene and Holocene surface ruptures of the Saline River fault zone, we tentatively assign paleo-earthquakes related to this liquefaction to movement on the faults of that zone. Sites with Pleistocene liquefaction features have a similar proximity to these faults, suggesting that Pleistocene and Holocene earthquakes in this area may have had comparable magnitudes. 
Table 2 | AMS (accelerator mass spectrometry) radiocarbon age analyses results.

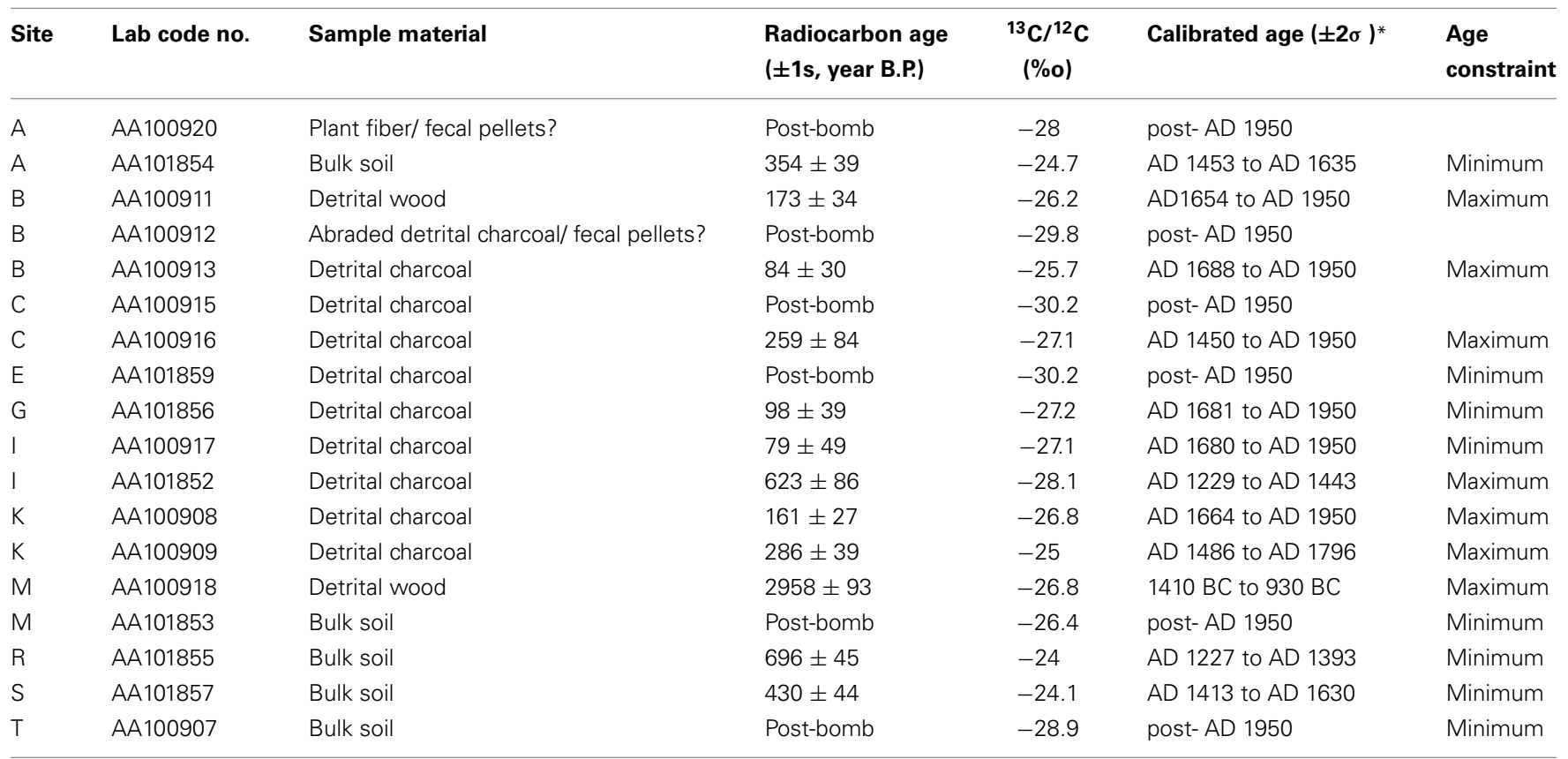

Samples analyzed by the NSF-Arizona AMS Laboratory.

${ }^{*}$ Following Stuiver et al. (2005).

Table 3 | Quartz OSL (optical stimulated luminescence) age analyses results. Samples analyzed by the USGS, Luminescence lab, Lakewood, Colorado.

\begin{tabular}{|c|c|c|c|c|c|c|c|c|c|c|}
\hline Site & $\begin{array}{l}\% \text { Water } \\
\text { content }^{a}\end{array}$ & $K(\%)^{b}$ & $U(p p m)^{b}$ & Th $(p p m)^{b}$ & $\begin{array}{l}\text { Cosmic dose } \\
(G y / k a)^{c}\end{array}$ & $\begin{array}{c}\text { Total dose } \\
\text { rate }(\mathrm{Gy} / \mathrm{ka})\end{array}$ & $\begin{array}{l}\text { Equivalent } \\
\text { dose (Gy) }\end{array}$ & $n^{d}$ & $\begin{array}{c}\text { Scatter } \\
\text { e(\%) }\end{array}$ & $\begin{array}{c}\text { Age } \\
\text { (years) }^{f}\end{array}$ \\
\hline 1 & $9(28)$ & $0.43 \pm 0.02$ & $1.43 \pm 0.08$ & $4.44 \pm 0.23$ & $0.17 \pm 0.01$ & $1.14 \pm 0.04$ & $0.48 \pm 0.03$ & $11(24)$ & 69 & $420 \pm 30$ \\
\hline
\end{tabular}

${ }^{a}$ Field moisture, with figures in parentheses indicating the complete sample saturation \%. Ages calculated using approx. $50 \%$ of the saturated moisture.

${ }^{b}$ Analyses obtained using high-resolution gamma spectrometry (Ge detector).

${ }^{c}$ Cosmic doses and attenuation with depth were calculated using the methods of Prescott and Hutton (1994).

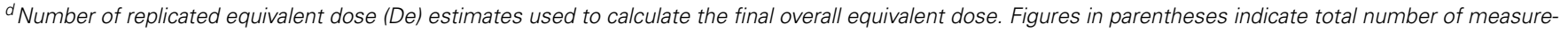
ments included in calculating the represented equivalent dose and age using the mean from the radial plot of equivalent doses.

eDefined as "over-dispersion" of the De values. Obtained by taking the average divided by SD. Values > 35\% are considered to be poorly bleached or mixed (i.e., bioturbation or fast fluvial).

${ }^{f}$ Dose rate and age for fine-grained 250-180 or 180-125 micron sized quartz. Exponential fit used on equivalent doses, errors to one sigma, ages, and errors rounded.

Our radiocarbon data are not precise enough to use the liquefaction record to correlate paleo-earthquakes from site to site, but the time intervals constrained by the ages at five sites within $24 \mathrm{~km}$ of each other (B, C, I, K, and M) overlap from AD 1750 to AD 1688 and could record a single earthquake. Thus, geographic proximity and timing constraints permit interpretation of a moderate earthquake in this area about $\mathrm{AD} 1700$ (before settlement of this region) as the cause of the liquefaction features at these five sites (Figures 2B, 12). Fluvial strata assigned to this time interval at Sites A, G, R, and T do not display liquefaction features. Although Site $\mathrm{G}$ is located amidst the sites that have liquefaction features, fluvial strata at the site are too strongly burrowed (Figure 9) for us to infer an absence of liquefaction features at this site. Undisturbed fluvial strata at Sites A, R, and T suggest that the macroseismic area of our hypothetical AD 1700 earthquake did not extend to these sites (Figure 12).

The locations of Sites R and T, which show no evidence of liquefaction, suggest that the Bradley County sand blow field may not be continuous with either the Desha County or Ashley County sand blow fields (Figures 2, 12). The sediments at Site $\mathrm{T}$ were deposited after AD 1564, and we know that Site R sediments are older than AD 1393. The Bradley County field had liquefaction events circa AD 960-610 and AD 610-260 (Cox et al., 2010). Sediments at Site T post-date these liquefaction events, and because we only have minimum ages at Site $\mathrm{R}$ we do not know if sediments at Site R post-date the events. Thus, we cannot use the absence of liquefaction at Sites $\mathrm{R}$ and $\mathrm{T}$ to limit the eastern and northeastern extent of the Bradley County field. Similarly, 


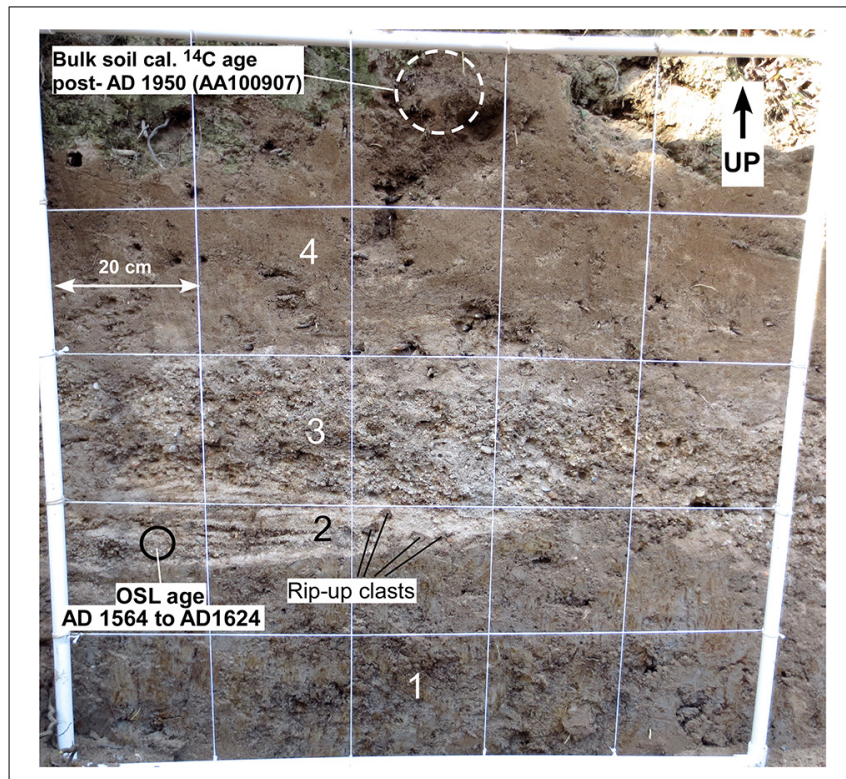

FIGURE 10 | Site T (Flat Creek, 33.36869 ${ }^{\circ}$, $9^{1.85048^{\circ}} \mathrm{W}$ ) - Top is up. Photograph of $1 \times 1 \mathrm{~m}$ grid on vertical excavation. No liquefaction observed. Unit 1, Flat Creek overbank, massive silty clay; Unit 2, Flat Creek point-bar, thin-bedded, fine sand; Unit 3, Flat Creek point-bar, medium-bedded sandy gravel; Unit 4, Flat Creek overbank, massive loam (aggraded A soil horizon). The bulk soil ${ }^{14} \mathrm{C}$ age from Sample AA100907 post-dates deposition of Units 1 through 3but does not constrain sediment deposition to before the historic period (our minimum constraint). The quartz OSL age (Table 2) gives the age of Unit 2 deposition and pre-dates deposition of Units 3 and 4.

sediments at Site S (Figure 2) are older than AD 1630 (Table 2), but we do not know if they are old enough to place a western limit on the Bradley County liquefaction field. However, surface fault ruptures at Gee's Landing and Horsehead Island are within the Bradley County field and in close proximity to the sand blows there (Cox et al., 2012), and we interpret these faults as the seismic source zone for the Bradley County liquefaction. From these data we infer that the magnitudes of paleo-earthquakes related to the Bradley County sand blow field are probably in the low part of the range known to cause sand venting (M 5-5.5).

An ellipse with a $12-\mathrm{km}$ maximum radius can be fitted to enclose the seismically-induced liquefaction features at Sites B, I, K, and M (Figure 2B), and Ambraseys' (1988) distance/magnitude relation gives an estimate of $M 5.5$ for the $\sim \mathrm{AD}$ 1700 earthquake. Possible evidence for liquefaction at nearby Site $\mathrm{C}$ also falls within this ellipse. This geographic clustering of soft sediment deformation features is consistent with a seismic origin for the features.

Although the timing of this liquefaction event is not well constrained, the slight ground shaking that was felt $170 \mathrm{~km}$ away by missionaries on the Mississippi River in December AD 1699 near the site of Helena, Arkansas (Wheeler et al., 2003) may have been caused by an earthquake in Drew County recorded by these liquefaction features. A post-5100 year B.P. surface rupture in Drew County, Arkansas (Cox et al., 2000) (at "B" on Figure 1) near the center of the 12-km-long ellipse may be the earthquake that caused this liquefaction. Alternatively, a post- AD

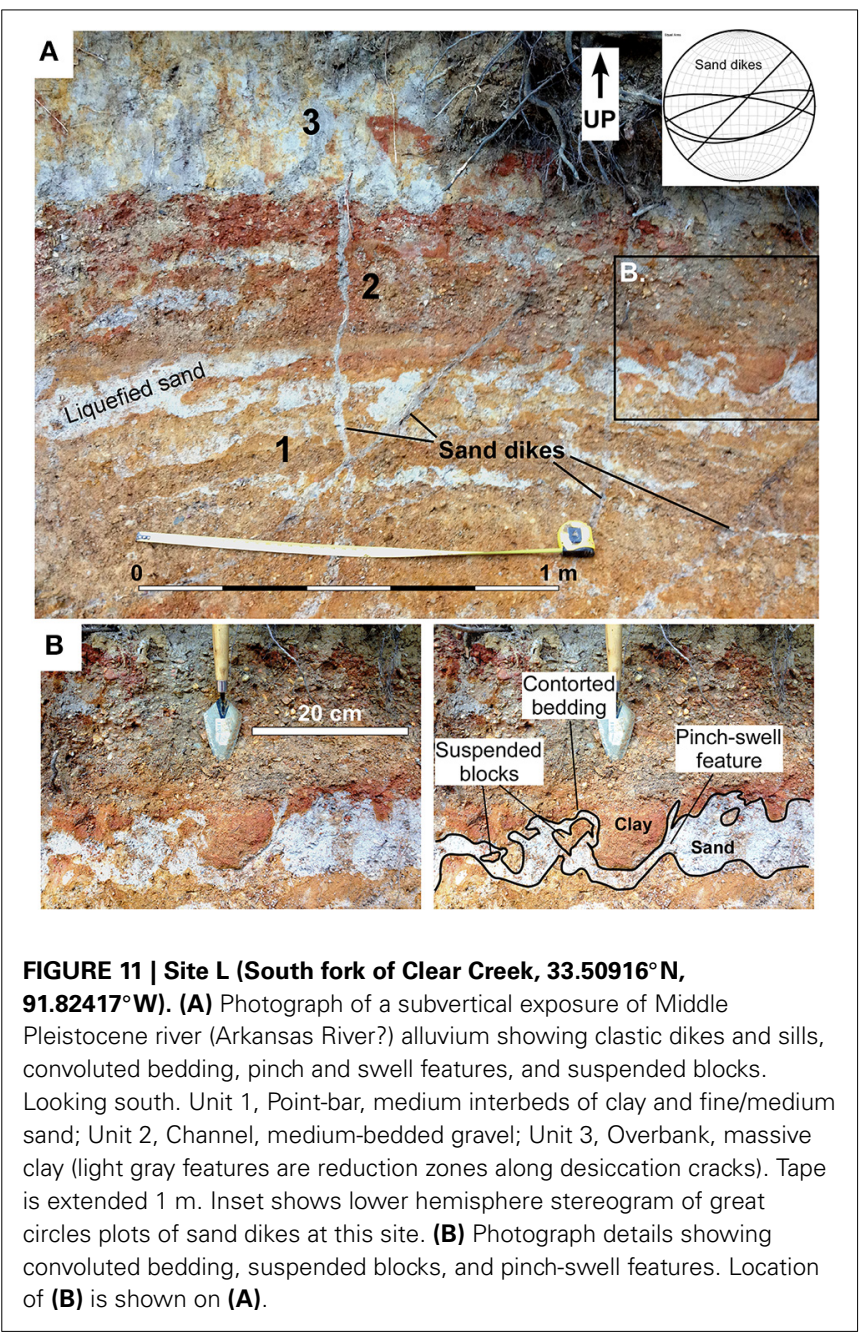

1200 surface rupture in the Saline River fault zone in Cleveland County, Arkansas (Cox et al., 2012) (at "A" on Figure 1) is a possible candidate for the earthquake that caused the $\sim \mathrm{AD} 1700$ liquefaction. However, continuation of the Cleveland County surface rupture $50 \mathrm{~km}$ southeastward to this cluster of liquefaction sites would require a much greater earthquake of $M$ 7 (Wells and Coppersmith, 1994). The width limitations that Sites $\mathrm{A}, \mathrm{R}$, and $\mathrm{T}$ impose on this liquefaction field suggests instead that the liquefaction is the result of shaking during rupture of a shorter nearby fault that probably did not extend to Cleveland County. The apparent restricted width of this liquefaction field makes it unlikely that the shaking it records came from a distant seismic source such as the New Madrid seismic zone.

The ages from Site A suggests liquefaction there predates the $\mathrm{AD} 1700$ event. If Site A records an AD 700-AD 1100 event previously described by Cox et al. (2007) in the Desha County sand blow field (Figures 2B, 12), then the distance to the farthest liquefaction for this field increases from 25 to $30 \mathrm{~km}$. Using Ambraseys' (1988) distance/magnitude relation, this increase suggests that the AD 700-AD 1100 event may have been M6.3, rather than M6.1 as previously estimated by Cox et al. (2007). 

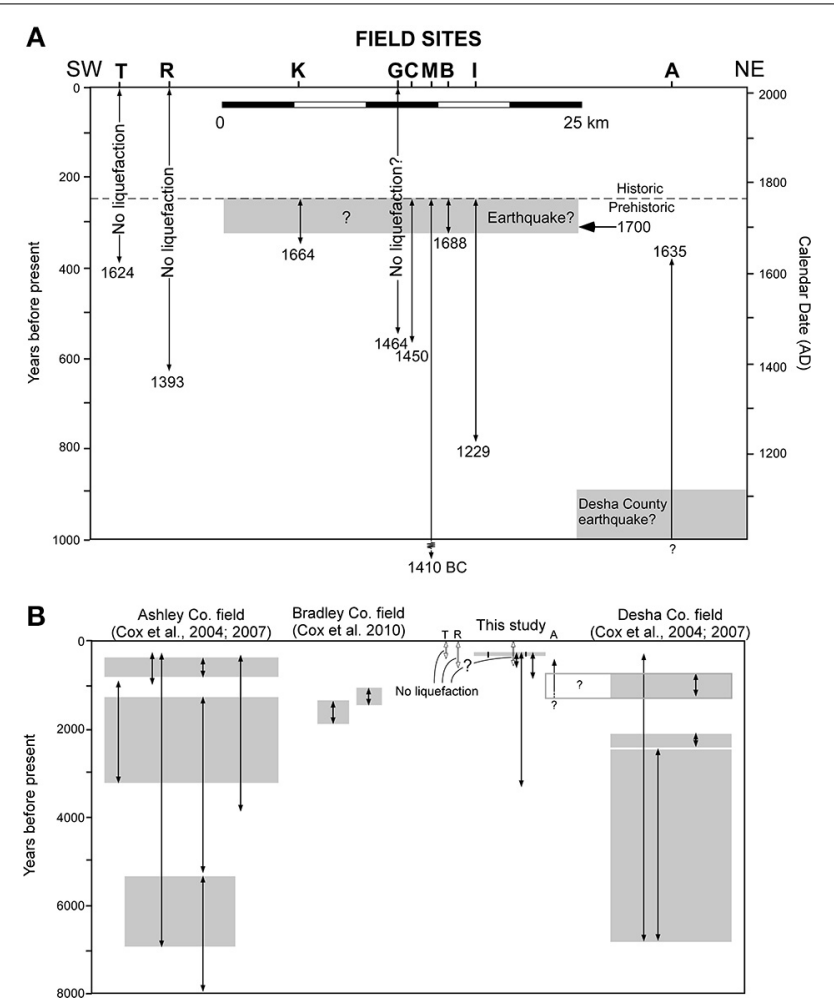

FIGURE 12 | (A) Time chart showing age ranges (vertical lines) for the generation of the liquefaction features as constrained by radiocarbon dates and historic records at 7 sites. The locations of field sites that display liquefaction were projected perpendicularly to a NE-SW-trending transect. The beginning of the historic period is placed at $\sim A D 1750$ (Hanson and Moneyhon, 1989). Shading denotes possible correlations of liquefaction features at field sites to paleo-earthquakes. (B) Time chart showing age ranges for liquefaction events in adjacent sand blow fields. Gray shading denotes the time range in which a paleo-earthquake may have occurred.

\section{CONCLUSIONS}

Soft-sediment deformation features in our study area include sand dikes and sills, detached blocks suspended in structureless sand, water escape structures, pinch-swell features, and convoluted bedding. We interpret these features to have formed through liquefaction of alluvial sediment during strong ground shaking because they conform to the criteria for recognition of seismically-triggered liquefaction, because they are geographically and temporally clustered, and because they are found near a Holocene fault in the Saline River fault zone (Wheeler, 2002; Counts and Obermeier, 2012). A cryoturbation origin for the features is less likely because the study area is well south of significant ground freezing and frost action and because no Holocene cryoturbation is reported in the region, and a lake impoundment origin is ruled out because no lacustrine sediments were observed.

Our results show that paleoseismic liquefaction features have a restricted distribution within our study area. We infer from our field searches for features that the sand blow fields within the study area (Ashley County field, Bradley County field, and Desha County field) probably do not overlap. For this reason, we do not argue for a paleo-earthquake of sufficient magnitude (M 6.7 by the Ambraseys distance/magnitude relation) to account for a liquefaction field equal to an area encompassing all three of these fields. However, timing constraints on a liquefaction event at Site A permit correlation with the youngest liquefaction event in the Desha County field. If this correlation is correct, the increase in the mapped size of that field increases the magnitude inferred for this event from $M$ 6.1-M 6.3. Geographic clustering and the temporal overlap of age constraints from five sites (B, C, I, K, and $\mathrm{M}$ ) lead us to interpret an M 5.5 earthquake $\sim \mathrm{AD} 1700$ with an epicenter near a post-5.1 ka surface rupture on a fault of the Saline River fault zone. This interpretation rules out a hypothetical late Holocene rupture on this fault that propagated from Cleveland County, Arkansas (northwest of this paleo-epicenter) to the Ashley County sand blow field $90 \mathrm{~km}$ to the southeast.

This study demonstrates that in settings like the Saline River fault zone, where detection of sand blows by remote sensing imagery is limited by forest cover and poor exposure, a search for small-scale liquefaction features in meter-scale excavations is inexpensive and may be an effective method of defining the size of liquefaction fields. Knowing the location, earthquake chronology, and size of liquefaction fields helps us to define seismic source zones and identify paleo-earthquakes, data that are critical for improving the assessment of seismic hazards in regions of low to moderate seismicity. Systematic inspection of Holocene alluvium for liquefaction features would significantly aid in identifying additional seismic source zones in the Coastal Plain.

\section{ACKNOWLEDGMENTS}

This manuscript was greatly improved by helpful comments from Rich Koehler, Roy Van Arsdale, and the two additional reviewers. This research was supported by the U.S. Geological Survey (USGS), Department of the Interior, under USGS award number G12AP20099. The views and conclusions contained in this document are those of the authors and should not be interpreted as necessarily representing the official policies, either expressed or implied, of the U.S. Government.

\section{REFERENCES}

Adelsberger, K. A., and Kidder, T. R. (2007). "Climate change, landscape evolution, and human settlement in the lower Mississippi Valley, 5500-2400 cal B.P.," in Reconstructing Human-Landscape Interactions, eds L. Wilson, P. Dickinson, and J. Jeandron (Newcastle upon Tyne: Cambridge Scholars Publishing), $84-108$.

Allen, T. E., and Touchet, B. A. (1990). "Geomorphic evolution and soils," in Search for the Lost Sixth Ridge: The 1989 Excavations at Poverty Point, Report No. 9, ed J. L. Gibson (Lafayette, LA: Center for Archaeological Studies. University of Southwestern Louisiana), 21-25.

Ambraseys, N. N. (1988). Engineering seismology. Earthquake Eng. Struct. Dynamics 17, 1-105. doi: 10.1002/eqe.4290170101

Aslan, A., and Autin, W. (1998). Holocene flood-plain soil formation in the southern lower Mississippi Valley: implications for interpreting alluvial paleosols. Bull. Geol. Soc. Am. 110, 433-449.

Bedinger, M. S, and Reed, J. E. (1961). "Geology and ground-water resources of Desha and Lincoln Counties, Arkansas," in Arkansas Geological and Conservation Commission, Water Resources Circular No. (Little Rock, AR) 6, 127.

Brodzikowski, K., and Haluszczak, A. (1987). "Flame structures and associated deformations in Quaternary glaciolacustrine and glaciodeltaic deposits: examples from central Poland," in Deformation of Sediments and Sedimentary Rocks, eds M. E. Zones and R. M. F. Preston (London, UK: Geol. Soc., Special Publ. 29), 279-286. doi: 10.1144/GSL.SP.1987.029.01.21 
Burnett, A. W., and Schumm, S. A. (1983). Alluvial-river response to neotectonic deformation in Louisiana and Mississippi. Science 222, 49-50. doi: 10.1126/science.222.4619.49

Calais, E., Han, J. Y., DeMets, C., and Nocquet, J. M. (2006). Deformation of the North American Plate interior from a decade of continuous GPS measurements. J. Geophys. Res. 111, B06402. doi: 10.1029/2005JB004253

Cole, M. R. (1977). Eocene Paleocurrents and Sedimentation, San Nicolas Island, California. Am. Assoc. Petroleum Geologists Bull. 61, 237-247.

Counts, R., and Obermeier, S. (2012). "Seismic signatures: small-scale features and ground fractures," in Recent Advances in North American Paleoseismology and Neotectonics East of the Rockies, eds R. T. Cox, M. P. Tuttle, O. S. Boyd, and J. Locat (Boulder, CO: Geological Society of America Special Paper 493), 203-220.

Cox, R. T. (1991). Possible triggering of earthquakes by underground waste disposal in the El Dorado, Arkansas area. Seismol. Res. Lett. 62, 113-122.

Cox, R. T. (1994). Analysis of drainage-basin symmetry as a rapid technique to identify areas of possible Quaternary tilt-block tectonics: an example from the Mississippi Embayment. Geol. Soc. Am. Bull. 106, 571-581.

Cox, R. T., Van Arsdale, R. B., Harris, J. B., Forman, S. L., Beard, W., and Galluzzi, J. (2000). Quaternary faulting in the southern Mississippi Embayment and implications for tectonics and seismicity in an intraplate setting. Geol. Soc. Am. Bull. 112, 1724-1735. doi: 10.1130/0016-7606(2000) 112\%3C1724:QFITSM\%3E2.0.CO;2

Cox, R. T., Larsen, D., Forman, S. L., Woods, J., Morat, J., and Galluzzi, J. (2004). Preliminary assessment of sand blows in the southern Mississippi Embayment. Bull. Seismol. Soc. Am. 94, 1125-1142. doi: 10.1785/0120030130

Cox, R. T., Hill, A. A., Larsen, D., Holzer, T., Forman, S. L., Morat, J., et al. (2007). Seismotectonic implications of sand blows in the southern Mississippi Embayment. Eng. Geol. 89, 278-299. doi: 10.1016/j.enggeo.2006.11.002

Cox, R. T., Gordon, J., Forman, S., Brezina, T., Negrau, M., Machin, S., et al. (2010). Paleoseismic sand blows in north Louisiana \& South Arkansas. Seismol. Res. Lett. 81, 1032-1047. doi: 10.1785/gssrl.81.6.1032

Cox, R. T., Harris, J., Forman, S., Brezina, T., Gordon, J., Gardner, C., et al. (2012). "Holocene faulting on the Saline River fault zone, Arkansas, along the AlabamaOklahoma transform," in Recent Advances in North American Paleoseismology and Neotectonics East of the Rockies, eds R. T. Cox, M. P. Tuttle, O. S. Boyd, and J. Locat (Boulder, CO: Geological Society of America Special Paper 493), 143-174.

Cox, R. T., Hall, J. L., and Gardner, C. S. (2013a). Tectonic history and setting of a seismogenic intraplate fault system that lacks microseismicity: the Saline River fault system, southern United States. Tectonophysics 608, 252-266. doi: 10.1016/j.tecto.2013.09.031

Cox, R. T., Lowe, C., and Hao, Y. (2013b). "Investigation of the magnitude and timing of paleo-earthquakes in Southeast Arkansas," in USGS-NEHRP Grant G12AP20099 Final Technical Report (Reston, VA).

Cushing, E. M., Boswell, E. H., and Hosman, R. L. (1964). "General geology of the Mississippi embayment," in U.S. Geological Survey Professional Paper 448-B. (Washington, DC), 28.

Follmer, L. R. (1996). Loess studies in the central United States: evolution and concepts. Eng. Geol. 45, 287-304. doi: 10.1016/S0013-7952(96)00018-X

Hanson, G. T., and Moneyhon, C. H. (1989). Historical Atlas of Arkansas. Norman, OK: University of Oklahoma Press.

Harry, D. L., and Londono, J. (2004). Structure and evolution of the central Gulf of Mexico continental margin and coastal plain, southeast United States. Geol. Soc. Am. Bull. 116, 188-199. doi: 10.1130/B25237.1

Hosman, R. L. (1996). "Regional stratigraphy and subsurface geology of cenozoic deposits, Gulf Coastal Plain, South-Central United States," in U.S. Geological Survey Professional Paper 1416-G. (Washington, DC), 35.

Larance, F. C., Gill, H. V., and Fultz, C. L. (1976). Soil Survey of Drew County, Arkansas. Department of Agriculture, Soil Conservation Service (Washington, DC).

Meade, B. K. (1975). Geodetic surveys for monitoring crustal movements in the U.S. Tectonophysics 29, 103-112. doi: 10.1016/0040-1951(75)90136-5

McNulty, W. E., and Obermeier, S. F. (1999). Liquefaction evidence for at least two strong Holocene paleo-earthquakes in central and southwestern Illinois, USA. Environ. Eng. Geosci. 5, 133-146.

Mickus, K. L., and Keller, G. R. (1992). Lithospheric structure of the south-central United States. Geology 20, 335-338.

Munson, P. J., Munson, C. A., Bleuer, N. K., and Labitzke, M. D. (1992). Distribution and dating of prehistoric earthquake liquefaction in the Wabash Valley of the central U.S. Seismol. Res. Lett. 58, 337-342.
Munson, P. J., Obermeier, S. F., Munson, C. A., and Hajic, E. R. (1997). Liquefaction evidence for Holocene and latest Pleistocene seismicity in the southern halves of Indiana and Illinois: a preliminary overview. Seismol. Res. Lett. 68, 521-536. doi: 10.1785/gssrl.68.4.521

Murray, G. E. (1961). Geology of the Atlantic and Gulf Coastal Province of North America. New York, NY: Harper and Bros.

Nichols, R. J., Sparks, R. S. J., and Wilson, C. J. N. (1994). Experimental studies of the fluidization of layered sediments and the formation of fluid escape structures. Sedimentology 41, 233-253. doi: 10.1111/j.1365-3091.1994.tb01403.x

Obermeier, S. F. (1998). Overview of liquefaction evidence for strong earthquakes of Holocene and latest Pleistocene ages in the states of Indiana and Illinois, USA. Eng. Geol. 50, 227-254. doi: 10.1016/S0013-7952(98)00032-5

Obermeier, S. F., Martin, J. R., Frankel, A. D., Youd, T. L., Munson, P. J., Pond, E. C., et al. (1993). "Liquefaction evidence for strong holocene earthquake(s) in the Wabash Valley of Southern Indiana-Illinois, with a preliminary estimate of magnitude," in USGS Professional Paper 1536. (Boulder, CO), 27.

Officer, L. B., and Drake, C. L. (1981). Epeirogenic plate movements. J. Geol. 90, 139-153. doi: 10.1086/628659

Onellion, F. E. (1956). Geology and ground-water resources of Drew County, Arkansas," in Water Resources Circular No. 4 (Arkansas Geological and Conservation Commission), 6-14.

Owen, G. (1996). Experimental soft-sediment deformation structures formed by the liquefaction of unconsolidated sands. Sedimentology 43, 279-293. doi: 10.1046/j.1365-3091.1996.d01-5.x

Owen, G. (2003). Load structures: gravity-driven sediment mobilization in the shallow subsurface. Geol. Soc. Lond. Spec. Publ. 216, 21-34. doi: 10.1144/GSL.SP.2003.216.01.03

Prescott, J. R., and Hutton, J. T. (1994). Cosmic ray contribution to dose rates for luminescence and ESR dating: large depths and log-term time variations. Radiat. Meas. 23, 497-500. doi: 10.1016/1350-4487(94)90086-8

Ross, J. A., Peakall, J., and Keevil, G. M. (2011). An integrated model of extrusive sand injectites in cohesionless sediments. Sedimentology 58, 1693-1715. doi: 10.1111/j.1365-3091.2011.01230.x

Salvador, A. (1991). "Origin and development of the Gulf of Mexico basin," in The Gulf of Mexico Basin, Vol. J, ed A. Salvador (Boulder, CO: Geological Society of America, The Geology of North America), 389-444.

Saucier, R. T. (1994). Geomorphology and Quaternary Geologic history of the Lower Mississippi Valley. Vicksburg, MS: U.S. Army Corps of Eng., Waterways Experiment Station.

Saucier, R. T., and Fleetwood, A. R. (1970). Origin and chronological significance of late Quaternary terraces, Ouachita River, Arkansas and Louisiana. Geol. Soc. Am. Bull. 81, 869-890. doi: 10.1130/0016-7606(1970)81[869:OACSOL]2.0.CO;2

Saucier, R. T., and Smith, L. M. (1986). Geomorphic Mapping and Landscape Classification of the Ouachita and Saline River Valleys, Arkansas. Report No. 51. Nashville, AR: Arkansas Archeological Assessments.

Saucier, R. T., and Snead, J. I. (1989). "Quaternary Geology of the Lower Mississippi Valley," in Louisiana Geological Survey, 1 Sheet, Scale 1:1,000,000 (Baton Rouge, LA).

Sawyer, D. S., Buffler, R. T., and Pilger, R. H. (1991). "The crust under the Gulf of Mexico basin," in The Gulf of Mexico Basin, Vol. J, ed A. Salvador (Boulder, CO: Geological Society of America, The Geology of North America), 53-72.

Schumm, S. A., Watson, C. C., and Burnett, A. W. (1982). "Phase 1: neotectonic activity within the Lower Mississippi Valley Division," in Potamology Program Report No. 2 (Vicksburg, MS: U.S. Army Corps of Engineers, Lower Mississippi Valley Division), 158

Selker, J. S. (1993). Expressions for the formation of load casts in soft sediment. J. Sediment. Petrol. 63, 1149-1151.

Sims, J. D. (2012). "Earthquake-induced load casts, pseudonodules, ball-and-pillow structures, and convolute lamination: additional deformation structures for paleoseismic studies," in Recent Advances in North American Paleoseismology and Neotectonics East of the Rockies, eds R. T. Cox, M. P. Tuttle, O. S. Boyd, and J. Locat (Boulder, CO: Geological Society of America Special Paper 493), 191-202.

Stamm, J. F., Hendricks, R. R., Sawyer, J. F., Mahan, S. A., Zaprowski, B. J., Geibel, N. M., et al. (2013). Late Quaternary stream piracy and strath terrace formation along the Belle Fourche and lower Cheyenne Rivers, South Dakota and Wyoming. Geomorphology 197, 10-20. doi: 10.1016/j.geomorph.2013. 03.028

Stuiver, M., Reimer, P. J., and Reimer, R. W. (2005). CALIB 5.0.2. Available online at: http://calib.qub.ac.uk/calib/ 
Thomas, P. J., Reddy, D. V., Kumar, D., Nagabhushanam, P., Sukhija, B. S., and Sahoo, R. N. (2007). Optical dating of liquefaction features to constrain prehistoric earthquakes in Upper Assam, NE India-some preliminary results. Quat. Geochronol. 2, 278-283. doi: 10.1016/j.quageo. 2006.03.013

Thomas, W. A. (2006). Tectonic inheritance at a continental margin. GSA Today 16, 4-11. doi: 10.1130/1052-5173(2006)016[4:TIAACM]2.0.CO;2

Tuttle, M. P. (2001). The use of liquefaction features in paleoseismology: lessons learned in the New Madrid seismic zone, central United States. J. Seismol. 5, 361-380. doi: 10.1023/A:1011423525258

Tuttle, M. P., and Hartleb, R. D. (2012). CEUS Paleoliquefaction Database, Uncertainties Associated with Paleoliquefaction Data, and Guidance for Seismic Source Characterization. Appendix E, Central and Eastern United States Seismic Source Characterization for Nuclear Facilities, Electric Power Research Institute Report \# 1021097. Palo Alto, CA.

Tuttle, M. P., and Schweig, E. S. (1996). Recognizing and dating prehistoric liquefaction features: Lessons learned in the New Madrid seismic zone, central United States. J. Geophys. Res. 101(B3), 6171-6178. doi: 10.1029/95JB 02894

Tuttle, M. P., Schweig, E. S., Sims, J. D., Lafferty, R. H., Wolf, L. W., and Haynes, M. L. (2002). The earthquake potential of the New Madrid seismic zone. Bull. Seismol. Soc. Am. 92, 2080-2089. doi: 10.1785/0120010227

Tuttle, M. P., Al-Shukri, H., and Mahdi, H. (2006). Very large earthquakes centered southwest of the New Madrid seismic zone 5,000-7,000 years ago. Seismol. Res. Lett. 77, 755-770. doi: 10.1785/gssrl.77.6.755

Wells, D. L., and Coppersmith, K. J. (1994). New empirical relationships among magnitude, rupture length, rupture width, rupture area and surface displacement. Bull. Seismol. Soc. Am. 84, 974-1002.

Wheeler, R. L. (2002). "Distinguishing seismic from nonseismic softsediment structures: criteria from seismic-hazard analysis," in Ancient Seismites, Vol. 359, eds
F. R. Ettensohn, N. Rast, and C. E. Brett (Boulder, CO: Geological Society of America Special Paper), 1-11.

Wheeler, R. L., Omdahl, E. M., Dart, R. L., Wilkerson, G. D., and Bradford, R. H. (2003). Earthquakes in the Central United States-1699-2002. U.S. Geological Survey Geologic Investigations Series I-2812, Poster, 1 Sheet (Washington, DC).

Wilbert, L. J. (1953). “The Jacksonian Stage in Southeastern Arkansas,” in Bulletin 19 (Little Rock, AR: Arkansas Resource \& Development Commission, Division of Geology), 125.

Zoback, M. L. (1992). Stress field constraints on intraplate seismicity in eastern North America. J. Geophys. Res. 97(B8), 11761-11782. doi: 10.1029/92JB00221

Conflict of Interest Statement: The Associate Editor Alan R. Nelson declares that, despite being affiliated to the same institution as author Shannon A. Mahan, the review process was handled objectively and no conflict of interest exists. The authors declare that the research was conducted in the absence of any commercial or financial relationships that could be construed as a potential conflict of interest.

Received: 30 April 2014; accepted: 14 October 2014; published online: 13 November 2014.

Citation: Cox RT, Lowe C, Hao Y and Mahan SA (2014) Use of small-scale liquefaction features to assess paleoseismicity: an example from the Saline River fault zone, Southeast Arkansas, USA. Front. Earth Sci. 2:31. doi: 10.3389/feart.2014.00031

This article was submitted to Quaternary Science, Geomorphology and Paleoenvironment, a section of the journal Frontiers in Earth Science.

Copyright (C) 2014 Cox, Lowe, Hao and Mahan. This is an open-access article distributed under the terms of the Creative Commons Attribution License (CC BY). The use, distribution or reproduction in other forums is permitted, provided the original author(s) or licensor are credited and that the original publication in this journal is cited, in accordance with accepted academic practice. No use, distribution or reproduction is permitted which does not comply with these terms. 